
8 Concepción, Chile.

9 Abstract Rebolledo Gajardo ${ }^{b}$ Zaragoza, Spain.

\title{
Assessing the environmental benefit of a new fertilizer based on activated biochar
} applied to cereal crops

Ana González-Cencerradoa, Javier Pallarés Ranz ${ }^{a}$, María Teresa López-Franco Jiménez ${ }^{a}$, Boris

anstituto CIRCE (Universidad de Zaragoza-Fundación CIRCE), Mariano Esquillor Gomez 15, 50018,

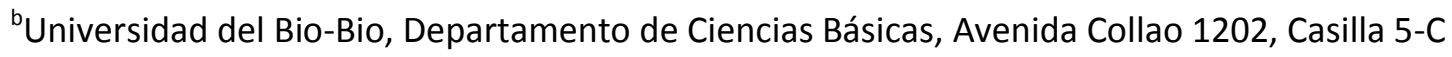

This study analyzes the environmental benefits that a nitrogen fertilizer based on activated biochar has in comparison to other traditional fertilizers (urea, ammonium nitrate (AN), ammonium sulfate (AS) and di-ammonium phosphate (DAP)). With this aim, activated biochar was generated from residual biomass (barley straw) through physical activation and the resulting biochar was combined with mineral fertilizer to synthethise the fertilizer. This new product was subjected to environmental assessment by means of two different approaches, Life Cycle Assessment (LCA) and nitrogen footprint procedure, both of which considered standard conditions typical of Mediterranean climate and wheat and corn as the fertilized crops. Emission factors of traditional fertilizers were obtained from internally developed models, which were in turn based on real data from literature. As for emission factors of the new product, they were calculated basing on experimental results. Fertilizer impacts in terms of acidification, eutrophication and climate change were estimated, thus revealing a great performance of activated biochar over other fertilizers in terms of reactive nitrogen $(\mathrm{Nr})$, reaching a maximum saving rate of $63 \%$ in the amount of $\mathrm{Nr}$ released by volatilization and leaching. In addition, this work offers a methodology 
24 for environmental analysis of fertilizers and provides useful quantitative indicators for the 25 environmental benefit and the saving of reactive nitrogen, which could contribute to the 26 development of new commercial low $\mathrm{N}$-emissions fertilizers.

27 Keywords: nitrogen fertilizer, activated biochar, LCA, reactive nitrogen

28 1. Introduction

29 One of the main environmental challenges that society must face today is the serious alteration of 30 the natural cycle of Nitrogen $(\mathrm{N})$ as a consequence of the high content of reactive nitrogen (Nr) 31 released to the environment. This effect is largely due to nitrogen fertilization, which is 32 undoubtedly one of the greatest achievements of modern society but also a source of 33 environmental damage. Intensification of agricultural production is the result of significant growth 34 population over the last century. One of the environmental threats associated with this 35 intensification is the impact of mineral nitrogen fertilizers [1.].

36 In the agricultural sector, Nr has always been a limiting nutrient, since optimal levels of both 37 biological $\mathrm{N}$ fixation and $\mathrm{Nr}$ recycling are required to increase production. Plants are able to 38 directly assimilate $\mathrm{Nr}$ in the form of nitrates $\left(\mathrm{NO}_{3}{ }^{-}\right)$and ammonium $\left(\mathrm{NH}_{4}{ }^{+}\right)$[2.], which may be 39 present in the soil as a result of natural mineral deposits, artificial fertilizers, animal manure, 40 organic matter decomposition or atmospheric deposition. In agriculture, a large part of the 41 fertilizers nitrogen is released to the environment. This $\mathrm{Nr}$ excess either enters into the 42 hydrological system through leaching, flow and groundwater runoff, or else it is emitted to the 43 atmosphere. Once released, the $\mathrm{Nr}$ moves through the natural ecosystem (biota) and the physical 44 environment, changing forms and flowing through the soil, water and air, and thus triggering 45 several undesired consequences [3.]. This is known as the nitrogen cascade first described by 46 Galloway, which is based on the fact that the geographical extent of the Nr effects increases over 
47 time. Thus the effects of the $\mathrm{Nr}$ in the short term are mainly local or regional, while their different

48 forms (for example, $\mathrm{NH}_{3}, \mathrm{NO}_{x}, \mathrm{NO}_{3}$ ) can have a variety of specific effects. However, the same $\mathrm{Nr}$ 49 atom can cause over time multiple effects on the atmosphere, terrestrial ecosystems, freshwater 50 and marine systems, as well as in human health [4.].

51 Sustainable agriculture requires the use of appropriate fertilizers that favor the reduction of these 52 emissions to the environment. In this context, biochar soil treatment is a reported strategy in the 53 mitigation of nitrogen emissions in agricultural sector [5.] to improve soil fertility [6.] and 54 agricultural $\mathrm{N}$-cycle [7.], which encourages its use as a fertilizer. According to several bibliographic 55 sources biochar amendments may provide environmental benefits such as carbon sequestration, 56 reduction of nitrate leaching [8.] and reduction in $\mathrm{N}_{2} \mathrm{O}$ flux in treatments containing biochar [9.]. 57 Some studies states that the combined application of biochar and nitrogen fertilizer benefits 58 nitrogen retention towards near-root areas [10.] as well as grain yield, nitrogen uptake and soil 59 carbon content [11.].

60 Moreover, the microcrystalline structure created during the activation process of biochar from 61 carbonaceous materials confers it an excellent adsorption capacity, which offers a further 62 advantage in its use as a complement to nitrogen as it enables it to capture a variety of chemical 63 species through chemical or physical processes [12.]. There are numerous studies that prove its 64 positive effect on agricultural soils by improving crop yields [13.],[14.],[15.],[6.], reducing $\mathrm{N}_{2} \mathrm{O}$ 65 [16.],[17.] and $\mathrm{NH}_{3}$ emissions [5.] and nitrate leaching [18.],[19.].

66 The double-fold objective of the present study is to determine the environmental benefit 67 produced by application of a biochar-based fertilizer as opposed to traditional fertilizers, as well as 68 to quantify the achieved reduction of reactive nitrogen losses through volatilization and leaching. 
69 To this end, a biochar-based fertilizer was synthesized from activated biochar of barley straw and

70 its benefits were analyzed for a particular case study.

71 Environmental analysis are usually based on LCA methodology which has become a very common

72 approach for identifying, quantifying and evaluating the potential environmental impacts of

73 production processes or products [1.]. Defined in the standard ISO 14040 [1.], this method consists

74 in of gathering and evaluating input and output data for its production or use and assessing its

75 potential effects on the environment during its life cycle [20.]. According to the guidelines

76 described by the norm, the system boundaries of the case study can comprise raw materials

77 procurements, production, utilization and final storage [21.].

78 Previously published LCA assessments on agricultural field, have focused on the environmental

79 impacts of different types of fertilizers. For example, Hasler et al. [22.] compared complex, bulk

80 blend and single nutrient fertilizers in order to analyze their environmental impact along their

81 whole supply chain. Martinez-Blanco et al. [23.] compared compost and mineral fertilizer in a

82 tomato Mediterranean production under open-field and standard greenhouse systems. Similarly,

83 Romero-Gámez et al. [24.] analyzed two different green bean cropping systems when different

84 mineral fertilizers were applied with the aim of improving the cultivation techniques, equipment,

85 and structures.

86 As for biochar assessment from a LCA point of view, previous research works have been focused

87 on the comparative evaluation of different schemes of biochar production using different

88 feedstocks [25.],[26.],[27.],[28.]. Other studies [29.] used the LCA analysis to evaluate possibilities

89 of neutralizing global warming impacts in crop production using biochar produced from side flows

90 and buffer-zone biomass. Also, the study performed by Qian et al. [30.] demonstrated that

91 compound organic/inorganic fertilizers with biochar from different feedstocks as $\mathrm{N}$ blinder

92 reduced GHGs emission in rice paddy fields. Nevertheless, none of the previous works focused on 
93 the study of the fertilizer during its application to the field. In contrast, this is considered a key

94 stage in the analysis, given the importance of $\mathrm{N}$-emissions losses through volatilization and

95 leaching in the field application of the fertilizer, because their impacts may substantially differ

96 among different fertilizers and are strongly influenced by the soil edaphic conditions, climate

97 conditions and crop management.

98 Among those impacts associated to mineral fertilizers, a difference must be made between 99 industrial production impacts and those produced during their application in agroecosystems. In 100 order to highlight the environmental effects of using the fertilizer in the field and compare the 101 level of impact of different products, this work takes into account only the effects of the 102 application stage. In addition to this, LCA analysis usually involves the use of estimated indexes 103 derived from inputs and outputs data that comprise a multitude of parameters, giving rise to 104 qualitative indicators that offer interesting information on environmental risks but that do not 105 inform about the specific losses of reactive nitrogen. In contrast, other studies focused on 106 determining volatilization and leaching nitrogen loses [31.]-[59.]. Among these, the first one are 107 based on field studies, while leaching ones are based on simplified models of nitrogen and water 108 balances, since they basically depend on soil-related and climate-related parameters. Apart from 109 that, no detailed studies were found that analyzed global losses considering both processes in a 110 systematic way. In this sense, the environmental analysis carried out in this work maintains the 111 ease and usability of indicators while offering rigorous, quantitative information of the main 112 reactive nitrogen losses from the perspective of nitrogen footprint [60.]. In addition, the 113 methodology makes use of characteristic emission factors based on statistical analysis and on field 114 measurements, according to the basic parameters that govern volatilization and leaching 115 processes. 
116 The final results of the environmental analysis showed the ability of the biochar-based fertilizer to

117 save reactive nitrogen when it is applied to different cereal crops. The aim of the present study

118 was to provide a consolidated background for evaluating the sustainability of a new fertilizer

119 product based on activated biochar applied to conventional agro-ecosystems.

120

$121 \quad 2 . \quad$ Materials and methods

122 2.1. Biochar-based fertilizer

123 Biochar is the solid carbonaceous residue resulting from thermal conversion of biomass in an 124 oxygen-limited environment, typically through gasification or pyrolysis. There is a huge range of 125 potential feedstocks for biochar production, among which those based on lignocellulosic waste 126 were the most interesting from an environmental point of view [25.]. Like activated carbon, 127 biochar has multiple applications as an adsorption material, and this capacity can be enhanced 128 when biochar is activated [61.]. In this work, activated biochar was produced and used as matrix 129 for the fertilizer production.

Barley straw was the precursor material selected for the production of activated biochar. Barley is 131 the crop with the largest territorial base in Spain ( 2.5 million hectares, $19 \%$ of the total cultivated 132 area) and with distribution throughout the entire territory [62.]. In addition, it is one of the main 133 products contributing to world's diet. Apart from the use of grain, straw is also used in animal feed 134 and bedding as an inert vegetable cover in woody crops and for other energy uses. However, 135 several studies estimate an availability coefficient for these secondary uses that varies between 85 136 and $50 \%$, which means that between $15-50 \%$ of the residual biomass is not used. According to 137 data on barley production and estimations on waste end use, between 2 and $6 \mathrm{Mt}$ of the residual 138 barley straw remains unused. 
Moreover, barley shows good characteristics for biochar production such as low ash and high

140 volatile content, similar to those materials previously used as precursors in physical activation

141 processes [63.][64.][65.].

142 The physical activation method was carried out in two stages, carbonization at 500 으 and

143 activation at $800^{\circ} \mathrm{C}$ using carbon dioxide as activating agent. The text experimental rig is basically

144 consists of an externally heated quartz tubular reactor. Table 1 summarizes the main properties of

145 the activated biochar used in this study: ultimate analysis (CHNS Thermo Flash 1112 analyzer),

146 mineral matter composition (ICP-OES Thermo Elemental IRIS Intrepid) and $\mathrm{N}_{2}$ adsorption tests

147 results (ASAP 2020 Micromeritics gas sorption analyzer) specifying BET surface area $\left(\mathrm{S}_{\mathrm{BET}}\right.$ ),

148 micropore surface area $\left(S_{\text {micro }}\right)$, total pore $\left(V_{T}\right)$ and micropore volume $\left(V_{\text {micro }}\right)$. More details on the

149 process conditions and the physical-chemical characterization of the resulting activated biochar 150 can be found in our previous works [66.].

151

\begin{tabular}{|c|c|c|c|c|c|c|}
\hline \multirow{2}{*}{$\begin{array}{l}\text { Ultimate analysis } \\
\% \text { wt (dry basis) }\end{array}$} & C & H & $\mathbf{N}$ & $S$ & 0 & Ash \\
\hline & 51.88 & 0.50 & 1.98 & 0.17 & 10.29 & 35.18 \\
\hline \multirow{4}{*}{$\begin{array}{c}\text { Mineral content } \\
\mathrm{mg} / \mathrm{g}\end{array}$} & $\mathrm{Al}$ & $\mathrm{Ca}$ & $\mathrm{Cu}$ & $\mathrm{Fe}$ & K & $\mathrm{Mg}$ \\
\hline & 2.121 & 21.65 & 0.023 & 1.021 & 75.05 & 6.313 \\
\hline & Mn & $\mathrm{Na}$ & $\mathbf{P}$ & $S$ & $\mathrm{Ti}$ & $\mathrm{Zn}$ \\
\hline & 0.164 & 1.021 & 3.697 & 1.788 & 0.109 & 0.081 \\
\hline \multirow{2}{*}{$\begin{array}{c}\mathrm{N}_{2} \text { adsorption } \\
\text { isotherm at } \\
77 \mathrm{~K}\end{array}$} & $\begin{array}{c}S_{\text {BET }} \\
\left(\mathrm{m}^{2} / \mathrm{g}\right)\end{array}$ & $\begin{array}{l}S_{\text {micro }} \\
\left(\mathrm{m}^{2} / g\right)\end{array}$ & $\begin{array}{c}V_{T} \\
\left(\mathrm{~cm}^{3} / \mathrm{g}\right)\end{array}$ & $\begin{array}{l}V_{\text {micro }} \\
\left(\mathrm{cm}^{3} / \mathrm{g}\right)\end{array}$ & & \\
\hline & 789 & 778 & 0.3495 & 0.3268 & & \\
\hline
\end{tabular}

152 Table 1. Ultimate analysis (dry basis), mineral content (ICP-OES) and physisorption test results of activated biochar. 
154 The next stage in the fertilizer production process is the complex reaction of macro (N, P, K) and 155 micro-nutrients $\left(\mathrm{Ca}, \mathrm{Mg}, \mathrm{Zn}, \mathrm{K}, \mathrm{NH}_{4}{ }^{+}\right)$with the produced biochar. In order to achieve this, different 156 active principles are mechanically mixed with the biochar and then dried and conditioned (grinding 157 and sieving).

158 In order to analyze the potential benefit derived from applying biochar-based fertilizer to cereal 159 crops, its environmental impact was compared to that of four fertilizers (urea, ammonium sulfate 160 (AS), ammonium nitrate (AN) and diammonium phosphate (DAP)), traditionally used in the Spanish 161 agricultural sector [67.]. Crop management is defined by the concentration and appearance forms 162 of nutrient elements, which implies: fertilizer doses, application moments and how they should be 163 incorporated. Table 2 shows the nitrogen content of each fertilizer and the $\mathrm{N}$-form.

\begin{tabular}{lcccc}
\hline \multicolumn{1}{l}{ Fertilizer } & \multicolumn{4}{c}{ Nitrogen source } \\
& Total N (\%) & Ammonia N (\%) & Nitric N (\%) & Ureic N (\%) \\
& 46 & -- & -- & 46 \\
\hline Urea & 21 & 21 & -- & - \\
Ammonium sulfate (AS) & $33,5-34,5$ & $16,7-17,2$ & $16,7-17,2$ & - \\
Ammonium nitrate (AN) & 18 & 18 & -- & - \\
Diammonium phosphate (DAP) & 1,48 & -- & -- & 1,48 \\
Biochar-based Fertilizer & & & \\
\hline & Table 2. Nitrogen type and concentration in selected fertilizers.
\end{tabular}

166 2.2. Methodology

167 The global objective of the study is to create an evaluation procedure that determines the 168 environmental benefit offered by the use of a biochar-based fertilizer over traditional products, 
which can be accomplished through the saving of Nr. With this aim, the work carries out a

170 theoretical analysis supported by experimental results and bibliographic data analysis.

171 The methodology starts from predictive models developed from experimental and bibliographic

172 data regarding volatilization and leaching losses. These models result in specific emissions factors

173 which indicate the kilograms of substance (nitrate, ammonia and nitrous oxide) per kg of nitrogen

174 added. After that, LCA indicators are defined and calculated according to the emissions inventory.

175 This inventory also informs of the rate of $\mathrm{Nr}$ saving achieved by each fertilizer, which allows

176 classifying fertilizers according to their environmental benefit.

177 The methodology also relies on several instruments originally defined in sectors such as 178 environmental management or risks analysis [68.][69.]. Based on these, a tool was developed to 179 classify traditional fertilizers according to their impact on the environment, as well as to 180 objectively quantify the environmental benefit achieved by the new biochar-based fertilizer.

181 The outline of the environmental analysis is shown in figure 1:

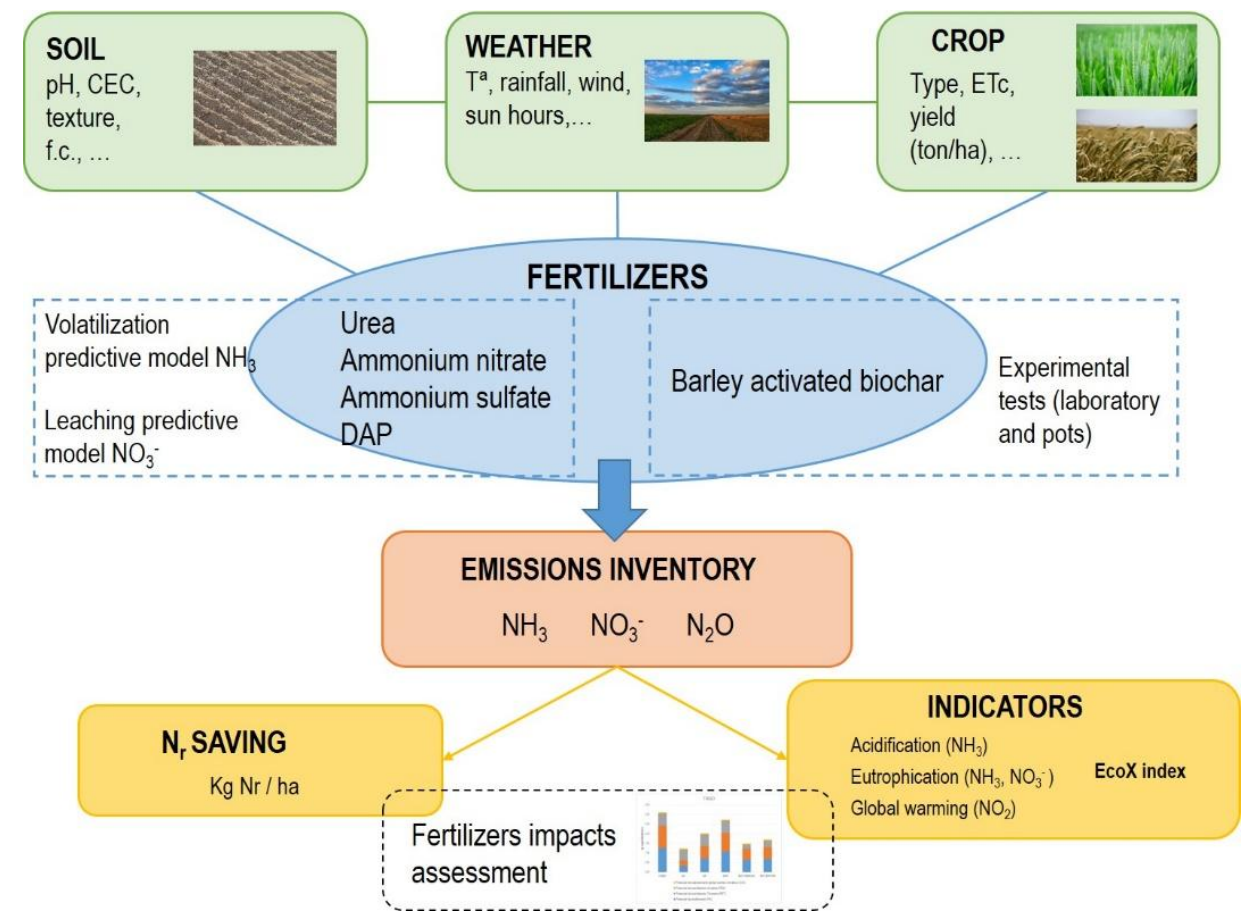


185 The analysis begins requires input data referring to soil, climate and crop. Then, internally 186 developed predictive models make use of input data to estimate the emission factors of both

187 volatilization and leaching of nitrogen compounds for four of the most used traditional fertilizers. 188 In contrast, for biochar-based fertilizer, these factors are obtained experimentally. The next step 189 consists in determining the emissions inventory for each fertilizer by defining the amount of 190 emitted nitrogen expressed in kg of compound per crop hectare. Environmental indicators of 191 acidification, eutrophication (terrestrial and aquatic) and global warming are calculated from the 192 inventory and lead to a final classification of the fertilizers in terms of their impact level. EcoX 193 index is also determined [76.] to aggregate all the indicators in a single value, thus allowing a 194 global comparison of the total environmental impact. Finally, the total amount of reactive nitrogen 195 contained in the nitrogen emissions is calculated for each fertilizer in the case study.

\subsubsection{Description of boundary conditions}

198 Most of the nitrogen applied through fertilization is lost as a result of volatilization in the form of 199 gaseous ammonia $\left(\mathrm{NH}_{3}\right)$ or nitrous oxide $\left(\mathrm{N}_{2} \mathrm{O}\right)$, as well as of leaching processes in the form of 200 nitrate $\left(\mathrm{NO}_{3}{ }^{-}\right)$. These losses are controlled by edaphic, climatic and crop management factors 201 which in turn depend on fertilizer and crop types and it is therefore essential to determine how all 202 these factors affect the rate of nitrogen losses. With this aim, predictive models require data on 203 the edaphic conditions of greater influence (temperature, $\mathrm{pH}$, field capacity, nitrogen content and 204 cation-exchange capacity (CEC)), on climate conditions (temperature, precipitation, wind, 
205 humidity, sun hours) and finally, on crop management (crop type, expected yield, 206 evapotranspiration rate, irrigation needs and fertilization rate).

207 In order to compare the reduction in nitrogen losses as well as the global environmental indicators 208 between biochar-based and traditional fertilizers, the predictive models developed in this work 209 were applied to two of the more widespread and traditional crops in the region of Aragon (Spain), 210 wheat and corn. Typical fertilizer doses for these crops were estimated in the present study as 150

$211 \mathrm{~kg} \mathrm{~N} / \mathrm{ha}$ and $300 \mathrm{~kg} \mathrm{~N} / \mathrm{ha}$, respectively, according to fertilization studies and regional agricultural 212 practice [67.]. Other relevant parameters regarding crop yields, nitrogen uptake, irrigation needs 213 and sowing time per hectare (ha) are shown table 3.

$$
\text { Crops properties: }
$$

\begin{tabular}{lccc}
\hline & WHEAT & $\underline{\text { CORN }}$ & \\
Expected production & 2 & 9 & ton/ha \\
Planting month & October & May & \\
Dose * & 150 & 300 & $\mathrm{~kg} \mathrm{~N} / \mathrm{ha}$ \\
Uptake N & 60 & 198 & $\mathrm{~kg} \mathrm{~N} / \mathrm{ha}$ \\
\hline *according to expected yield & & & \\
\hline
\end{tabular}

215 Local weather conditions (Aragón, Spain) were collected from regional weather stations during the 216 period 2014-2018. Mean values of temperature, rainfall, humidity, wind and sun were used for 217 estimations and input data model. A characteristic sandy clay loam soil in the region was selected, 218 considered the properties shown in Table 4.

Soil properties:

\begin{tabular}{lll}
\hline Bulk density & $1,35 \quad \mathrm{~g} / \mathrm{cm}^{3}$
\end{tabular}


Field capacity

Texture

Initial content of $\mathrm{N}$

$\mathrm{pH}$

Cation Exchange capacity (CEC)
0,34 $\quad \mathrm{kg} \mathrm{H}_{2} \mathrm{O} / \mathrm{kg}_{\text {soil }}$

Sandy clay loam

$50 \quad \mathrm{~kg} \mathrm{~N} / \mathrm{ha}$

8,5

$12,1 \quad \mathrm{meq} / 100 \mathrm{~g}$

Table 4. Soil properties

2.2.2. Estimation of nitrogen losses related to each fertilizer. Emission factors

221 Volatilization and leaching are the main processes involving nitrogen loses in agricultural sector.

222 Volatilization losses produced when applying mineral fertilizers are due to different chemical,

223 physical and biological processes and their magnitude depends on environmental, edaphic and

224 crops management factors. These losses are produced fundamentally in the form of $\mathrm{NH}_{3}$ and $\mathrm{N}_{2} \mathrm{O}$.

$225 \mathrm{NH}_{3}$ emissions are the most important in fertilization processes, accounting for nearly $90 \%$ of the

226 global emissions related to agriculture [70.]. They show important variation in the $\mathrm{N}$-form but also

227 they also are dependent on the climatic conditions and soil properties.

228 These factors and the specific fertilizer characteristics may significantly affect the amount of losses

229 due to volatilization under certain conditions. In order to determine the volatilization losses

230 associated to each fertilizer, a detailed statistical data study was performed, based on an extensive

231 revision of bibliographic data [31.]-[59.]. The analysis uses volatilization data from experimental

232 on-field trials with traditional fertilizers (urea, AS, AN and DAP), and it is based on variance analysis

233 of relevant factors, such as soil $\mathrm{pH}$, temperature, cation exchange capacity (CEC), $\mathrm{CO}_{3}$ content, clay

234 content, organic material content, nitrogen fertilizer dose and sampling time, and their

235 interactions. As a result, soil $\mathrm{pH}$, temperature and CEC have been identified as the most critical

236 target variables for the volatilization process in the soil-plant-atmosphere system. Finally, based 
on a multiple regression linear model different expressions were obtained to quantify

238 volatilization losses according to target variables.

239 In the regression model, the percentage of volatilized ammonia is expressed as a linear function of

240 the objective variables $\mathrm{pH}$, temperature, $\mathrm{CEC}$ and time.

$$
\% \mathrm{NH} 3=\beta 1+\beta 2(\mathrm{pH})+\beta 3(\mathrm{~T})+\beta 4(\mathrm{CEC})+\beta 5(\mathrm{t})+\varepsilon
$$

242 where $\beta 1, \beta 2, \beta 3, \beta 4, \beta 5$ are the regression coefficients that quantify the relationship between the 243 outcome variable and each independent variable, and $\varepsilon$ is the random error term, which accounts 244 for the influence of other variables not considered in the model. Determination of the regression 245 coefficients was performed by minimizing the mean squared error (MSE). Table 5 presents the 246 regression equations for ammonia losses due to volatilization of each fertilizer.

\begin{tabular}{|c|c|}
\hline & Urea \\
\hline$f(p H, T, C E C)$ & $\begin{array}{c}\% \mathrm{NH}_{3}=-66.77+3.98(\mathrm{pH})+1.81(\mathrm{~T})+0.68(\mathrm{CEC}) \\
\text { AS }\end{array}$ \\
\hline $\mathrm{f}(\mathrm{pH}, \mathrm{T}, \mathrm{CEC})$ & $\begin{array}{c}\% \mathrm{NH}_{3}=-29.674+3.127(\mathrm{pH})+0.211(\mathrm{~T})+0.761(\mathrm{CEC}) \\
\text { AN }\end{array}$ \\
\hline$f(p H, T, C E C)$ & $\begin{array}{c}\% \mathrm{NH}_{3}=-7.359+1.052(\mathrm{pH})+0.107(\mathrm{~T})+0.102(\mathrm{CEC}) \\
\text { DAP }\end{array}$ \\
\hline$f(p H, T, C E C)$ & $\% \mathrm{NH}_{3}=-36.16+4.14(\mathrm{pH})+0.54(\mathrm{~T})+0.49(\mathrm{CEC})$ \\
\hline
\end{tabular}
process.

249 In order to know the reduction on ammonia volatilization when biochar was added to the soil, an 250 experimental test campaign was conducted by analyzing different mixtures of biochar and soil 
251 before and after adding urea. The percentage of biochar used was $2 \%$ and the urea added was 252 about $5.12 \mathrm{~g}$. Soluble carbon and nitrogen were measured several times during a 7-day period. The 253 most relevant results were obtained for nitrogen content after 7 days, which shows a significant 254 ammonium retention when the mixture contains biochar, compared to that obtained in the soil 255 sample (without biochar). This results in a reduction of the $\mathrm{NH}_{3}$ released of about half in the case 256 of soil-biochar mixtures. There is therefore a retention of ammonium from urea, preventing its 257 transformation in $\mathrm{NH}_{3}$ and its loss by volatilization. Results show that the ammonia volatilization in 258 a soil fertilized with Urea is reduced in a $49.95 \%$ by adding $2 \%$ of biochar from barley straw.

$259 \mathrm{~N}_{2} \mathrm{O}$ emissions are produced after $\mathrm{NH}_{3}$ volatilization and they come from nitrification and 260 denitrification processes. Around $80 \%$ of the $\mathrm{N}_{2} \mathrm{O}$ emissions due to agriculture are related to the 261 use of mineral and organic fertilizers [70.]. Several interactions between soil and climate related 262 factors and other parameters determined by crop management influence the $\mathrm{N}_{2} \mathrm{O}$ emissions. 263 However, its contribution to the reactive nitrogen losses is much lower than that of $\mathrm{NH}_{3}$. In 264 addition, bibliographic data are not enough to develop a suitable statistical analysis. In order to 265 include its contribution to the model, the $\mathrm{N}_{2} \mathrm{O}$ emission factor was adopted from Bouwman (1995) 266 [71.] who proposed the following expression from field experiments with mineral and organic 267 fertilizers.

${ }^{a}$ the amount of $\mathrm{N}$ applied is corrected by eliminating the $\mathrm{NH}_{3}$ emissions since they occur before those of $\mathrm{N}_{2} \mathrm{O}$.

271 As for nitrogen leaching losses, these are directly related to deep drainage processes and depend 272 on local environmental factors [72.]. The key parameters involved in those processes are related 273 to soil and weather, but the net effect also depends on the result of the nitrogen balance in the 274 agricultural system. Field capacity in effective rooting zone [70.] is the fundamental parameter to 
275 calculate the leaching rate. It describes the soil capacity to absorb water in the roots zone and it

276 varies depending on the texture and soil type. Experimental on field investigations focused on

277 leaching processes are scarce and most of the published studies in the literature are based on

278 predictive models instead of direct measurements. Following a similar methodology, a simulation

279 model was here developed in order to estimate the nitrate losses through leaching associated to

280 each traditional fertilizer when applied to wheat and corn crops under particular conditions

281 (climatic, edaphic and crop management).

282 The developed leaching model accounts for the nitrogen transformations and interactions within

283 the agro-system cycle, where atmosphere and aquifers were considered as upper and lower limit,

284 respectively. Likewise, water dynamics is taken into account, through a balance of nitrogen and

285 water in the system, in order determine the nitrates that will leave the system by leaching. The

286 most important factors that determine the nitrate and water balance are related to crop type,

287 weather and crop management (evapotranspiration rate, effective precipitation, irrigation needs

288 among others)[73.]. The proposed model involves several key variables: nitrogen input (N)

289 expressed as $\mathrm{kg} \mathrm{N} / \mathrm{ha}$, drainage water \% (D), soil $\mathrm{pH}(\mathrm{pH})$, soil temperature (o C) (T), and field

290 capacity \% (f.c). Finally, following a similar methodology to that developed for volatilization losses,

291 different model simulations were run for the particular conditions of the study and a multiple

292 regression model was accordingly developed giving rise to the following expressions:

Urea

Wheat $\mathrm{NO}_{3 \_ \text {leached }}=1,047+5,62\left(10^{-5}\right) \mathrm{N}+0,052 \mathrm{D}-0,017 \mathrm{pH}-0,007 \mathrm{~T}-0,27 \mathrm{f} . \mathrm{c}$
Corn $\quad \mathrm{NO}_{3 \_ \text {leached }}=0,95+2,03\left(10^{-4}\right) \mathrm{N}+0,010 \mathrm{D}-0,015 \mathrm{pH}-0,007 \mathrm{~T}-0,037 \mathrm{f} . \mathrm{c}$

AS

Wheat $\mathrm{NO}_{3 \_ \text {leached }}=1,021+5,618\left(10^{-5}\right) \mathrm{N}+0,051 \mathrm{D}-0,027 \mathrm{pH}-0,002 \mathrm{~T}-0,270 \mathrm{f} . \mathrm{C}$ 


$$
\text { Corn } \quad \mathrm{NO}_{3} \text { leached }=0,917+2,208\left(10^{-3}\right) \mathrm{N}+0,009 \mathrm{D}-0,025 \mathrm{pH}-0,002 \mathrm{~T}-0,037 \mathrm{f} . \mathrm{c}
$$

AN

$$
\begin{aligned}
& \text { Wheat } \mathrm{NO}_{3 \_ \text {leached }}=0,915+5,618\left(10^{-5}\right) \mathrm{N}+0,054 \mathrm{D}-0,009 \mathrm{pH}-0,001 \mathrm{~T}-0,285 f . \mathrm{c} \\
& \text { Corn } \quad \mathrm{NO}_{3 \_ \text {leached }}=0,811+2,85\left(10^{-4}\right) \mathrm{N}+0,007 \mathrm{D}-0,009 \mathrm{pH}-9,266\left(10^{-4}\right) \mathrm{T}-0,030 f . \mathrm{c}
\end{aligned}
$$

DAP

$$
\begin{aligned}
& \text { Wheat } \mathrm{NO}_{3 \_ \text {leached }}=1,098+5,618\left(10^{-5}\right) \mathrm{N}+0,050 \mathrm{D}-0,034 \mathrm{pH}-0,005 \mathrm{~T}-0,265 f . \mathrm{c} \\
& \text { Corn } \quad \mathrm{NO}_{3 \_ \text {leached }}=0,998+1,782\left(10^{-4}\right) \mathrm{N}+0,011 \mathrm{D}-0,031 \mathrm{pH}-0,004 \mathrm{~T}-0,040 \mathrm{f} . \mathrm{c}
\end{aligned}
$$
according to fertilizer type.

295 Again, in order to determine the reduction on nitrates leaching when biochar was added to soil, an 296 experimental leaching test campaign was conducted. Pot experiments with the selected crops, 297 corn and wheat were performed to compare the extent of leaching. In this case, $70 \%$ of soil was 298 mixed with $30 \%$ of the biochar-based fertilizer. Experiments were conducted during 4 weeks 299 approximately, performing periodic irrigation and collecting and analyzing the leached samples. 300 After this period the resulting plants were collected and measured in order to obtain different 301 growth parameters. Results showed a reduction in nitrogen leaching from $37 \%$ to $14 \%$ compared 302 to another traditional fertilizer (urea). A $7 \%$ of increase in the $\mathrm{N}$ uptake by the crop was also 303 observed, which in practice resulted in a substantial improvement of the biometric parameters of 304 the plant (efficiency of the use of radiation, root growth rate, growth rate of the aerial part and $305 \mathrm{CO}_{2}$ fixation). 

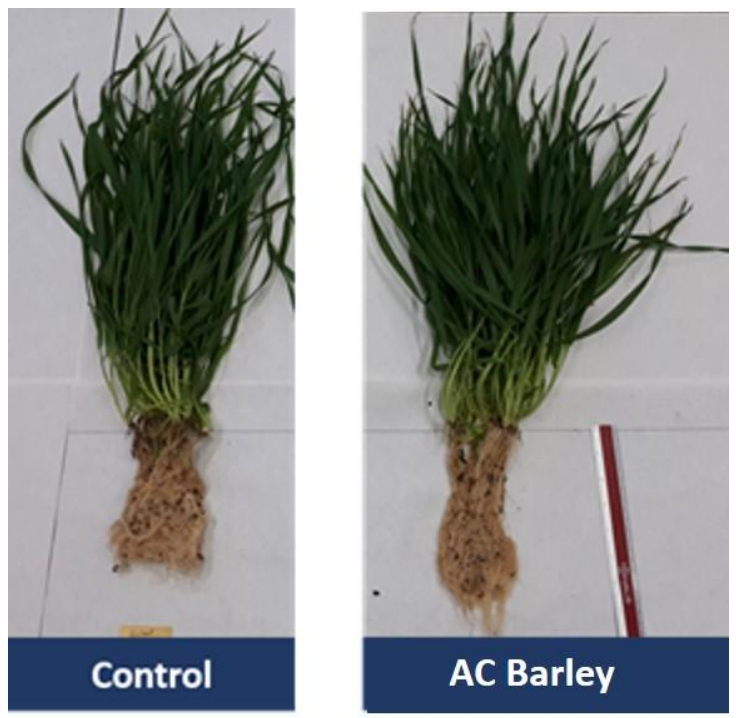

Figure 2. Plant growth comparison from pot trials of wheat (fertilization with control (urea) and biocharbased fertilizer).

309 After developing and validating the volatilization and leaching models, these were applied to the determination of the emission factors of ammonia and nitrate leaching for the four traditional

311 fertilizers. In the case of biochar-based fertilizer, factors were in turn obtained from the experimental tests.

313 An emission factor is a representative value that relates the quantity of a pollutant released to the 314 atmosphere with an activity associated with the release of that pollutant [74.]. In this work, 315 emission factors express the amount (in kilograms) of nitrogen in form of nitrate, ammonia or 316 nitrous oxide emitted per kg of nitrogen applied through fertilization. It can also be expressed as 317 percentage of the total amount of nitrogen applied. According to this, emission factors of urea, AS, $318 \mathrm{AN}$, and DAP are derived from expressions on table 5 and 6 using boundary conditions as input data. Table 7 shows the calculated emission factors of each fertilizer. 


\section{$\underline{\text { UREA }} \quad \underline{\mathrm{AN}} \quad \underline{\mathrm{AS}} \quad \underline{\mathrm{DAP}} \quad \underline{\mathrm{BB} F E R T}$.}

$\mathrm{NH}_{3}$ volatilization factor:

\begin{tabular}{|c|c|c|c|c|c|c|}
\hline ---- & $\mathrm{kg} \mathrm{N}-\mathrm{NH}_{3} / \mathrm{kg} \mathrm{N}$ applied & 0,2059 & 0,0549 & 0,1139 & 0,1849 & 0,0849 \\
\hline \multicolumn{7}{|c|}{$\mathrm{N}_{2} \mathrm{O}$ volatilization factor } \\
\hline ---- & $\mathrm{Kg} \mathrm{N} 2 \mathrm{O} / \mathrm{kg} \mathrm{N}$ applied & 0,0099 & 0,0118 & 0,0111 & 0,0102 & 0,0114 \\
\hline \multicolumn{7}{|c|}{$\mathrm{NO}_{3}$ leaching factor: } \\
\hline WHEAT & 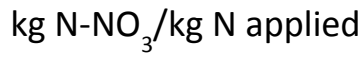 & 0,4077 & 0,4884 & 0,4569 & 0,4189 & 0,1384 \\
\hline CORN & $\mathrm{kg} \mathrm{N}-\mathrm{NO}_{3} / \mathrm{kg} \mathrm{N}$ applied & 0,5511 & 0,6647 & 0,6203 & 0,5669 & 0,1445 \\
\hline
\end{tabular}

323 An environmental analysis of data from predictive models and experimental tests was carried out 324 within the framework of risk analysis and footprint approach.

\subsubsection{Indicators description based on LCA impact categories}

326 Life Cycle Assessment (LCA) is a systematic process to identify and quantify the environmental

327 burdens associated with a product (or service) during its life cycle. The final objective is to evaluate 328 the environmental impacts derived from them and to define the measures or improvements 329 throughout the cycle. One of the fundamental steps on LCA is the characterization of impacts 330 according to different categories. It consists in transforming the collected data into impact 331 category or damage category indicators [75.] [1.]. LCA has been used in agriculture to evaluate 332 how existing products, including fertilizers, interact with their environment [1.]. 
Based on these categories, several environmental indicators were selected to represent the

334 environmental impact related to nitrogen losses.

335 Acidification. This impact is defined as the loss of the neutralizing capacity of soil and water, as a 336 consequence of the return to the earth's surface, in the form of acids, of the oxides of sulfur and 337 nitrogen released into the atmosphere [68.]. The acidification process takes place as a result of the $338 \mathrm{NH}_{3}, \mathrm{NOx}$ and $\mathrm{SO}_{2}$ emissions. $\mathrm{SO}_{2}$ and $\mathrm{NOx}$ are mainly originated from combustion processes 339 whereas $\mathrm{NH}_{3}$ is due to animal husbandry and volatilization during application of ammonia340 containing fertilizers [76.]. In the present study the substance considered for acidification impact is $341 \mathrm{NH}_{3}$. Acidification potential (AP) is expressed in kg equivalents of $\mathrm{SO}_{2}$ per ha (equation 1 ).

$$
A P=m_{N H_{\mathrm{g}}} * A F_{N H_{\mathrm{g}}}
$$

343 Where $m_{\mathrm{NH}_{\mathrm{g}}}$ is the $\mathrm{NH}_{3}$ mass expressed in $\mathrm{kg} \mathrm{NH} / \mathrm{ha}$, and $A F_{\mathrm{NH}}$ is the $\mathrm{NH}_{3}$ characterization

344 factor, which represents the potential of a single emission to contribute to the respective impact 345 category, considering deposition patterns and susceptibility to acidification determined for the 346 Spanish region [78.].

347 Eutrophication. This impact accounts for terrestrial and aquatic eutrophication impacts. Since 348 both the dynamics of the process and the species involved are different for both mechanisms, 349 independent potential impacts were defined for each contribution. [76.].

350 Terrestrial eutrophication potential (TEP) was defined to account for the most relevant 351 contributors to atmospheric deposition, $\mathrm{NOx}$ and $\mathrm{NH}_{3}$ [77.], being ammonia the only substance 352 taking part in the case study. A regionalized characterization factor developed by Huijbregts [78.], 353 considering atmospheric pathways, deposition patterns and eutrophication effects of $\mathrm{NH}_{3}$ 
354 emissions, was selected and used to calculate the potential. According to equation 2, TEP is 355 expressed in kg equivalents of NOx.

$$
T E P=m_{N H_{\mathrm{g}}} * E F_{N H_{\mathrm{g}}}
$$

357 Where $m_{N H_{\mathrm{g}}}$ in the mass of $\mathrm{NH}_{3}$ emission expressed in $\mathrm{kg} \mathrm{NH} / \mathrm{ha}$, and $E F_{N H_{\mathrm{g}}}$ the characterization

358 factor for terrestrial eutrophication impact corresponding to Spain, and expressed in kg NOx359 equivalents/ $\mathrm{kg} \mathrm{NH}$ emitted (see table 9).

360 Aquatic eutrophication potential (AEP), in addition to the atmospheric deposition of $\mathrm{NH}_{3}$ 361 considered in the previous category, must include the contribution of $\mathrm{NO}_{3}{ }^{-}$that reaches water 362 bodies as a consequence of leaching processes. Both contributions are considered in equation 3 363 and the potential impact is expressed in $\mathrm{kg}$ equivalents of $\mathrm{PO}_{4} /$ ha. Atmospheric deposition on 364 marine ecosystems caused by airborne $\mathrm{NH}_{3}$ emissions is difficult to estimate and fate factors 365 considering regional aspects are needed. Regionalized fate factor developed by Huijbregts et 366 al.[79.] for aquatic eutrophication sub-category was used (table 9) to this end. For the estimation 367 of $\mathrm{NO}_{3}{ }^{-}$leaching losses from soil to groundwater a reduction factor must be assumed since 368 denitrification process is produced on the way from groundwater to surface water and finally the 369 sea [76.]. According to Potting et al.[80.] this factor was set on $30 \%$.

$$
A E P=\left(m_{N_{\mathrm{g}}} \cdot F F_{\mathrm{NH}_{\mathrm{g}} \text { Spain }} \cdot E F_{\mathrm{NH}_{\mathrm{g}}}\right)+\left(\mathrm{m}_{\mathrm{NO3}} \cdot R F_{\mathrm{NO3}} \cdot E F_{\mathrm{NO3}}\right)
$$

371 Where $m_{N H_{\mathrm{I}}}$ is the mass corresponding to $\mathrm{NH}_{3}$ emission, expressed in $\mathrm{kg} \mathrm{NH} / \mathrm{ha}, \mathrm{FF}_{\mathrm{NH}}$,Spain is

372 the fate factor for $\mathrm{NH}_{3}$ airborne emissions corresponding to Spain, $E F_{N H_{3}}$ and $E F_{N O 3}$ are the 
373 eutrophication factors for $\mathrm{NH}_{3}$ and $\mathrm{NO}_{3}^{-}$(kg eq. $\mathrm{PO}_{4} / \mathrm{kg}$ ). Finally $\mathrm{RF}_{\mathrm{NO}}$ is the reduction factor for

374 nitrate immission to surface water.

375 Climate change. This category, also defined as global warming potential, express the contribution

376 of greenhouse gas emissions from agricultural production systems [76.]. The contribution to this

377 potential corresponds to $\mathrm{N}_{2} \mathrm{O}$ emissions produced during the fertilizer application. According to

378 this, in this study the expression used for the climate change potential was:

$$
C C P=m_{N_{2} \mathrm{O}} * G W P_{\mathrm{N}_{2} \mathrm{O}}
$$

380 Where $m_{\mathrm{N}_{2} \mathrm{O}}$ is the $\mathrm{N}_{2} \mathrm{O}$ expressed in $\mathrm{kg} \mathrm{N} \mathrm{N}_{2} \mathrm{O} /$ ha, and $G W P_{\mathrm{N}_{2} \mathrm{O}}$ is the global warming potential of

$381 \mathrm{~N}_{2} \mathrm{O}$.

382 Table 8 shows all the specific factors applied to the calculation of each potential risk linked to the 383 involved substance.

\section{Characterization factors applied:}

\begin{tabular}{|c|c|c|c|c|}
\hline Substance & Potential risk & Value & Units & Reference \\
\hline ammonia $\left(\mathrm{NH}_{3}\right)$ & Acidification (AF) & 0,27 & eq. $\mathrm{kg} \mathrm{SO} 2$ & [78.] \\
\hline ammonia $\left(\mathrm{NH}_{3}\right)$ & Aquatic eutrophication (AEF) & 0,35 & eq. $\mathrm{kg} \mathrm{PO} 4$ & [76.] \\
\hline ammonia $\left(\mathrm{NH}_{3}\right)$ & Terrestrial eutrophication (TEF) & 2,00 & eq. $\mathrm{kg} \mathrm{NO}$ & [78.] \\
\hline ammonium ion $\left(\mathrm{NO}_{3}^{-}\right)$ & Aquatic eutrophication (AEF) & 0,10 & eq. $\mathrm{kg} \mathrm{PO} 4$ & [76.] \\
\hline nitrous oxide $\left(\mathrm{N}_{2} \mathrm{O}\right)$ & Climate change (CCP) & 298 & eq. kg CO 2 & [81.] \\
\hline
\end{tabular}

385 In order to globally compare the environmental risk of each fertilizer, the obtained results from 386 indicators are subject to a normalization and weighting process, making it possible to obtain a 
387 global index that collects all the burdens. On the one hand, normalization process converts the 388 characterization results into neutral global units, dividing each one by a normalization factor. 389 Through these factors, the contribution degree of each impact category on the local 390 environmental problem is represented.

$$
N_{i}=\frac{I_{i}}{N V_{i}}
$$

392 Where $N_{i}$ is the normalization result for impact category $\mathrm{i}, I_{i}$ is the indicator value for impact

393 category I, and $N V_{i}$ is an indicator value according to a reference situation (e.g. per person in

394 Europe), all of these considering the functional unit (1 ha).

\begin{tabular}{|c|c|c|c|}
\hline Impact category & NV & WF & Units \\
\hline Climate change & 9730 & 1,06 & eq. $\mathrm{kg} \mathrm{CO} 2$ \\
\hline Acidification & 47,7 & 1,34 & eq. $\mathrm{kg} \mathrm{SO}{ }_{2}$ \\
\hline Aquatic eutrophication & 8,56 & 1,36 & eq. kg $\mathrm{PO}_{4}$ \\
\hline Terrestrial eutrophication & 60,7 & 1,26 & eq. $\mathrm{kg} \mathrm{NO}$ \\
\hline
\end{tabular}

397 On the other hand weighting factors represent the contribution of each impact category. The 398 standardized "distance-to-target" principle [76.] was considered for their calculation, comparing 399 the current level of an environmental effect in a certain region and time, with the target level of 400 that same effect. The ratio between both values provides the weighting factor for that 401 environmental effect. 
Finally, an aggregated environmental indicator, EcoX index, was defined in order to compare and

403 categorize all the fertilizers based on their global environmental impact. This index is the result of

404 adding all the normalized values of each impact category $\left(N_{i}\right)$ multiplied by their corresponding

405 weight factor $\left(W F_{i i}\right)$ and accounts for all the previous indicators in a single global value (equation

406 6).

407

$$
E \operatorname{coX}=\sum N_{i} \cdot W F_{i}
$$

Nitrogen footprint (NF) was introduced to express the total amount of reactive nitrogen lost to the environment as a consequence of human activity [60.]. Nevertheless the NF concept is very recent

411 and few nitrogen footprint models have been developed, being the $\mathrm{N}$-calculator tool developed by

412 Leach et al (2012) the most extensively known [82.]. Based on this model, reactive nitrogen losses

413 linked to fertilizer application were calculated. To express the contribution of each compound on

414 the total $\mathrm{Nr}$, it is necessary to determine the $\mathrm{N}$ that is contained in the molecule and multiply it by 415 the total amount of emitted substance. For the case of nitrogen emissions from fertilizer 416 application the following expression determines the total amount of reactive nitrogen.

$$
N_{r}=\frac{M(N)}{M\left(N H_{3}\right)} \times m\left(N H_{3}\right)+\frac{M\left(N_{2}\right)}{M\left(N_{2} O\right)} \times m\left(N_{2} O\right)+\frac{M(N)}{M\left(N O_{a}^{-}\right)} \times m\left(N O_{3}^{-}\right)
$$

418 Where $M(N)$ is the molar mass of nitrogen and $M\left(\mathrm{NH}_{3}\right)$ is the total molar mass of ammonia molecule, and thus for the rest of nitrogen compounds, respectively.

420 3. Results and discussion 
422 Table 10 gathers all the nitrogen emissions resulting from each fertilizer application on the

423 selected crops, considering the emission factors presented on section 2.2.2. The kilograms of $\mathrm{N}$ in

424 form of ammonia, nitrate and nitrous oxide per hectare are the basis for the environmental

425 analysis. Potential risks are calculated according to equations (1) to (4) and results are gathered in

426 table 11. Potential values are normalized and weighted by applying the equations (5) and (6), thus

427 presenting the environmental impact in terms of global risk.

\begin{tabular}{|c|c|c|c|c|c|c|}
\hline \multirow[t]{2}{*}{ Fertilizer } & \multicolumn{3}{|c|}{ WHEAT (150 kg N/ha) } & \multicolumn{3}{|c|}{ CORN (300 kg N/ha) } \\
\hline & $\mathrm{kg} \mathrm{NH}_{3} / \mathrm{ha}$ & $\mathrm{kg} \mathrm{NO}_{3}^{-} / \mathrm{ha}$ & $\mathrm{kg} \mathrm{N} \mathrm{N}_{2} \mathrm{O} / \mathrm{ha}$ & $\mathrm{kg} \mathrm{NH}_{3} / \mathrm{ha}$ & $\mathrm{kg} \mathrm{NO}_{3}^{-} / \mathrm{ha}$ & $\mathrm{kg} \mathrm{N}_{2} \mathrm{O} / \mathrm{ha}$ \\
\hline Urea & 30,88 & 61,16 & 1,49 & 61,76 & 165,34 & 2,98 \\
\hline DAP & 27,74 & 62,84 & 1,53 & 55,48 & 170,06 & 3,06 \\
\hline AS & 17,08 & 68,53 & 1,66 & 34,16 & 186,09 & 3,32 \\
\hline AN & 8,24 & 73,26 & 1,77 & 16,47 & 199,40 & 3,54 \\
\hline BB Fert. & 12,74 & 20,76 & 1,72 & 25,47 & 43,35 & 3,43 \\
\hline
\end{tabular}

\section{WHEAT}

Fertilizer AP (eq. AEP (eq. TEP (eq. $\quad$ CCP (eq. $\left.\left.\left.\mathrm{kg} \mathrm{SO}_{2}\right) \quad \mathrm{kg} \mathrm{PO}_{4}\right) \quad \mathrm{kg} \mathrm{NOx} \quad \mathrm{kg} \mathrm{CO}_{2}\right)$

\begin{tabular}{|c|c|c|c|c|c|c|c|c|}
\hline & $\mathrm{kg} \mathrm{SO}_{2}$ ) & $\left.\mathrm{kg} \mathrm{PO}{ }_{4}\right)$ & kg NOx) & $\left.\mathrm{kg} C \mathrm{CO}_{2}\right)$ & $\mathrm{kg} \mathrm{SO}_{2}$ ) & $\left.\mathrm{kg} \mathrm{PO}{ }_{4}\right)$ & kg NOx) & $\left.\mathrm{kg} C \mathrm{CO}_{2}\right)$ \\
\hline Urea & 8,34 & 3,56 & 61,76 & 443,73 & 16,67 & 8,42 & 123,51 & 887,45 \\
\hline DAP & 7,49 & 3,44 & 55,48 & 455,42 & 14,98 & 8,21 & 110,96 & 910,85 \\
\hline AS & 4,61 & 3,01 & 34,16 & 495,13 & 9,22 & 7,50 & 68,32 & 990,26 \\
\hline
\end{tabular}

\section{CORN}

AP (eq. $\quad$ AEP (eq. TEP (eq. $\quad$ CCP (eq. $\left.\left.\left.\left.\mathrm{kg} \mathrm{SO}_{2}\right) \quad \mathrm{kg} \mathrm{PO}_{4}\right) \quad \mathrm{kg} \mathrm{NOx}\right) \quad \mathrm{kg} \mathrm{CO}_{2}\right)$ 


\begin{tabular}{crrrr|rrrr}
\hline AN & 2,22 & 2,66 & 16,47 & 528,07 & 4,45 & 6,90 & 32,94 & 1056,15 \\
BB Fert. & 3,44 & 1,34 & 25,47 & 511,30 & 6,88 & 2,73 & 50,95 & 1022,61 \\
\hline
\end{tabular}

Table 11. Quantification of the environmental risk potential (due to acidification, eutrophication and climate change) of the selected fertilizers.

\begin{tabular}{ccccc|cccc}
\hline \multirow{2}{*}{ Fertilizer } & \multicolumn{3}{c}{ WHEAT } & \multicolumn{5}{c}{ CORN } \\
& AP & AEP & TEP & CCP & AP & AEP & TEP & CCP \\
\hline Urea & 0,23 & 0,57 & 1,28 & 0,05 & 0,47 & 1,34 & 2,56 & 0,10 \\
DAP & 0,21 & 0,55 & 1,15 & 0,05 & 0,42 & 1,30 & 2,30 & 0,10 \\
AS & 0,13 & 0,48 & 0,71 & 0,05 & 0,26 & 1,19 & 1,42 & 0,11 \\
AN & 0,06 & 0,42 & 0,34 & 0,06 & 0,12 & 1,10 & 0,68 & 0,12 \\
BB Fert. & 0,10 & 0,21 & 0,53 & 0,06 & 0,19 & 0,43 & 1,06 & 0,11 \\
\hline
\end{tabular}

$$
\text { /ha). }
$$

434 The results yielded by indicators inform about the level of impact of each fertilizer. 
a)
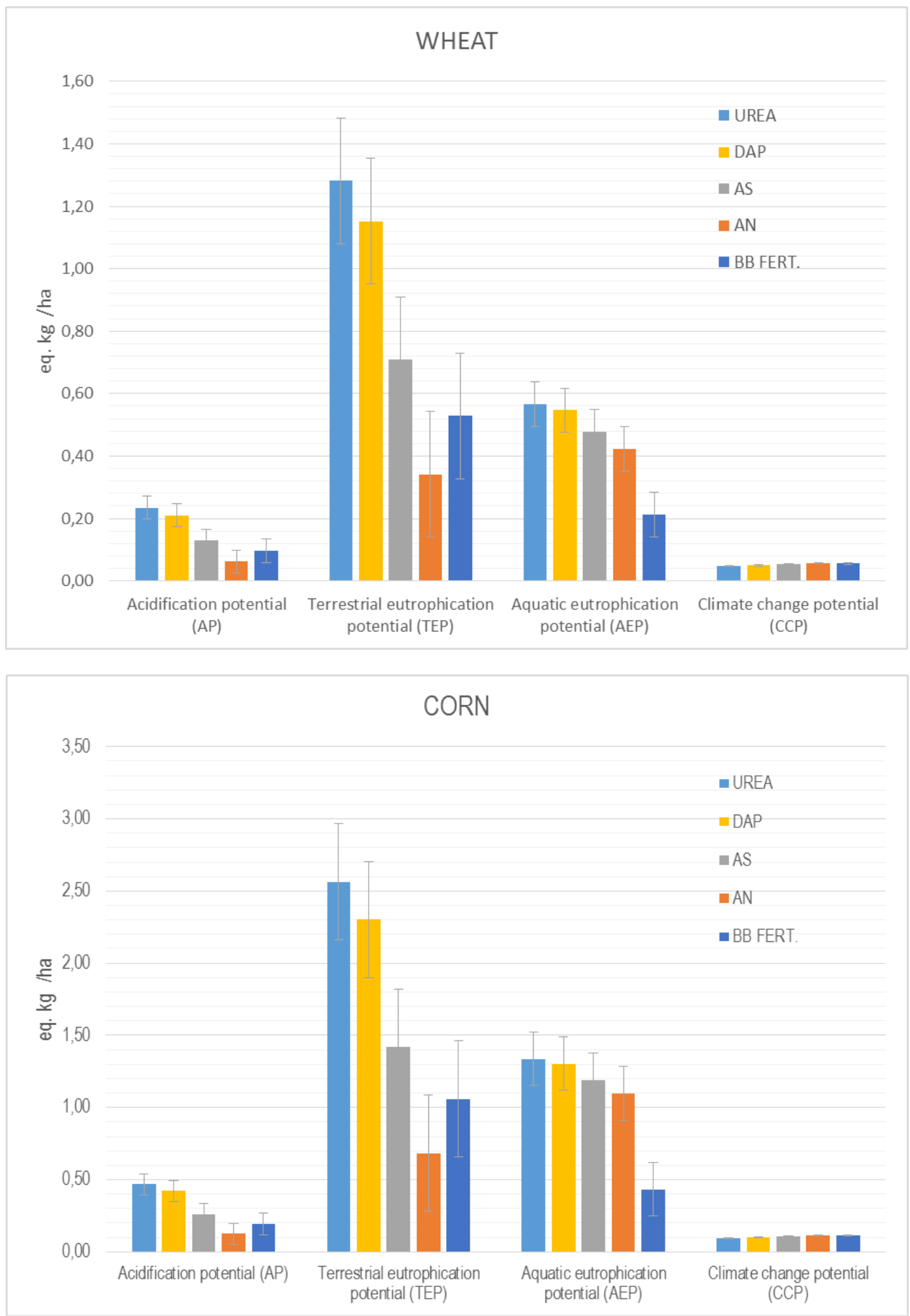

Figure 3. Environmental indicators results for selected fertilizers applied to a) wheat crops, and b) corn crops. 
439 As Figure 3 shows, a wide variability was detected between potential risks, among which

440 terrestrial and aquatic eutrophication risks were identified as the most significant. Also different

441 fertilizers were found to have widely different potential for environmental damage, among which

442 urea and DAP had the highest. AN shows the lowest risk in acidification and TE potentials thanks to

443 its low emission of $\mathrm{NH}_{3}$. The reason is that $\mathrm{AN}$ combines the advantages of containing nitric

444 nitrogen, of immediate availability, and ammonium nitrogen, with a longer action since it must

445 undergo the nitrification process. Nevertheless, its contribution of $\mathrm{NO}_{3}^{-}$is significant and that

446 penalizes its global environmental impact.

447 Regarding to aquatic eutrophication risk, the achieved reduction in the case of the biochar-based

448 fertilizer is $69 \%$ with respect to urea and $63 \%$ with respect to AN which means that more than half

449 of the nitrate losses produced by leaching are avoided. As for climate change potential, all

450 fertilizers show similar results, all of which contribute only to a small extent to the global

451 calculation, because $\mathrm{N}_{2} \mathrm{O}$ emissions are much lower than the other considered pollutants. In

452 general, it can be stated that the most important risk in nitrogen fertilization is eutrophication, not

453 only linked to nitrate leaching (aquatic eutrophication) but mostly because of the $\mathrm{NH}_{3}$ emissions

454 that contribute to the undesired increased in biomass production on terrestrial vegetation

455 (terrestrial eutrophication).

456 Although $\mathrm{NO}_{3}^{-}$(in $\mathrm{kg}$ of $\mathrm{N} / \mathrm{ha}$ ) emissions level is higher for traditional fertilizers, the aquatic

457 eutrophication potential is lower than TEP for the most of the cases. This is explained by the fact

458 that the environmental damage caused by the acidifying effect of ammonia is comparatively

459 greater than the impact of nitrates on aquatic ecosystems.

460 Acid deposition of $\mathrm{NH}_{3}$ emissions depends on deposition patterns and the potential damage of

461 acidifying emissions in the local natural ecosystems. In this work, acidification risk was found to be 
462 of little significance compared to eutrophication, because of it depends on the sensitivity of the 463 receiving area in terms of buffer capacity of soils and water or $\mathrm{CaCO}_{3}$ content [73.]. For instance, 1 $464 \mathrm{Kg}$ of $\mathrm{NH}_{3}$ released in Spain results in only $0.27 \mathrm{~kg} \mathrm{SO}$ equivalents when the same emission 465 released in Norway has an acidification potential of $6 \mathrm{~kg} \mathrm{SO}_{2}$ equivalents [78.]. For this reason, this 466 capacity of assuming acid deposits makes the potential risk less relevant in the considered region.

467 The contribution of each process into the impact categories is shown in Figure 4 for the case of 468 Urea in wheat crop. Whereas impact associated to AP, TEP is entirely (100\%) due to $\mathrm{NH}_{3}$ 469 volatilization, CCP is only linked to $\mathrm{N}_{2} \mathrm{O}$ emissions. In contrast, aquatic eutrophication (AEP) 470 depends on both $\mathrm{NH}_{3}$ volatilization and $\mathrm{NO}_{3}$ leaching processes and their contributions vary 471 substantially for each fertilizer. For mineral fertilizers, the contribution of $\mathrm{NH}_{3}$ volatilization is 472 always lower than $\mathrm{NO}_{3}$ leaching, whereas with the biochar-based fertilizer the contribution of 473 nitrate leaching is less important than ammonia volatilization (Figure 5).

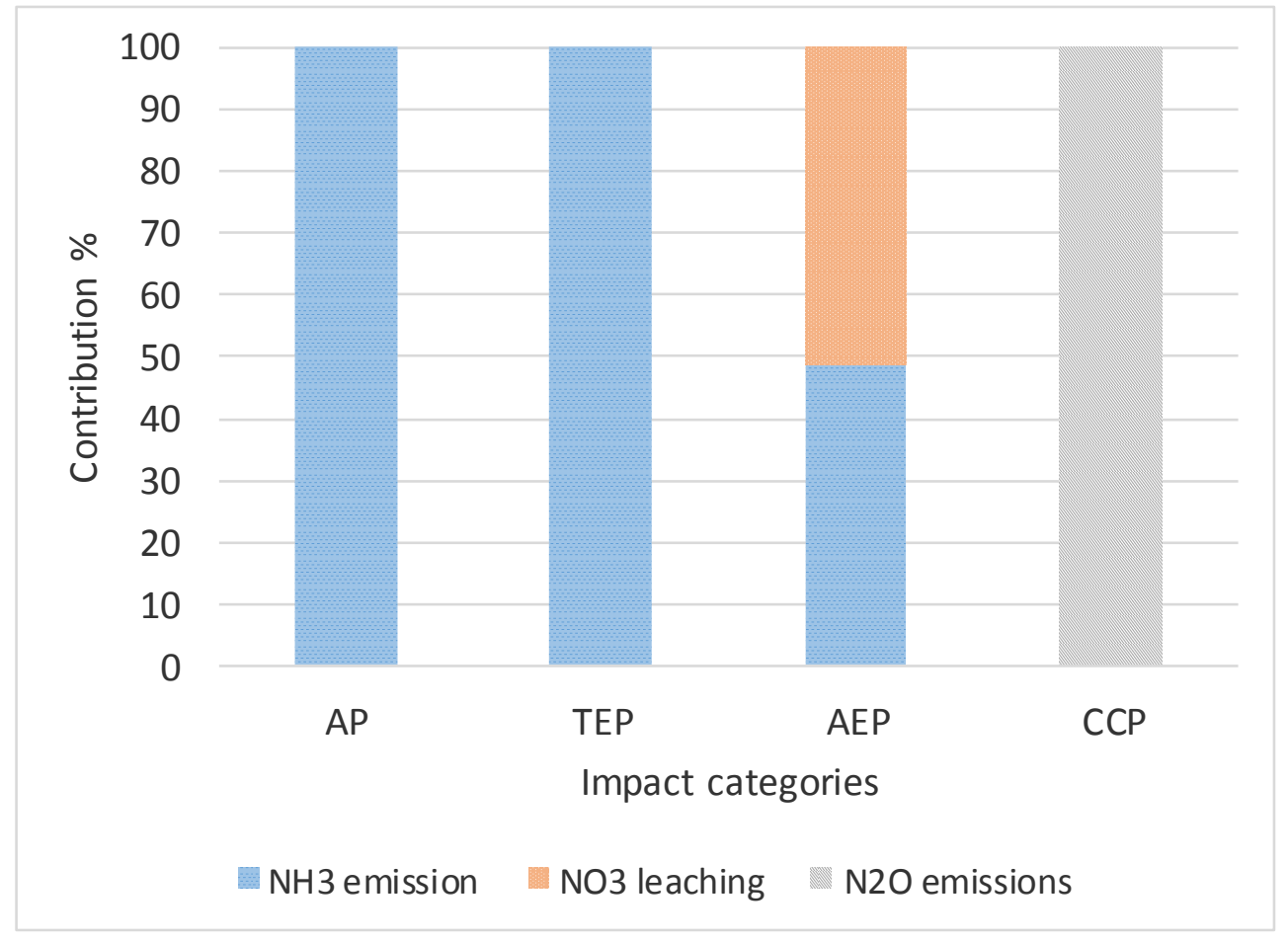


475

476

Figure 4. Contribution of each process into the impact categories corresponding to Urea fertilizer applied to a wheat crop.

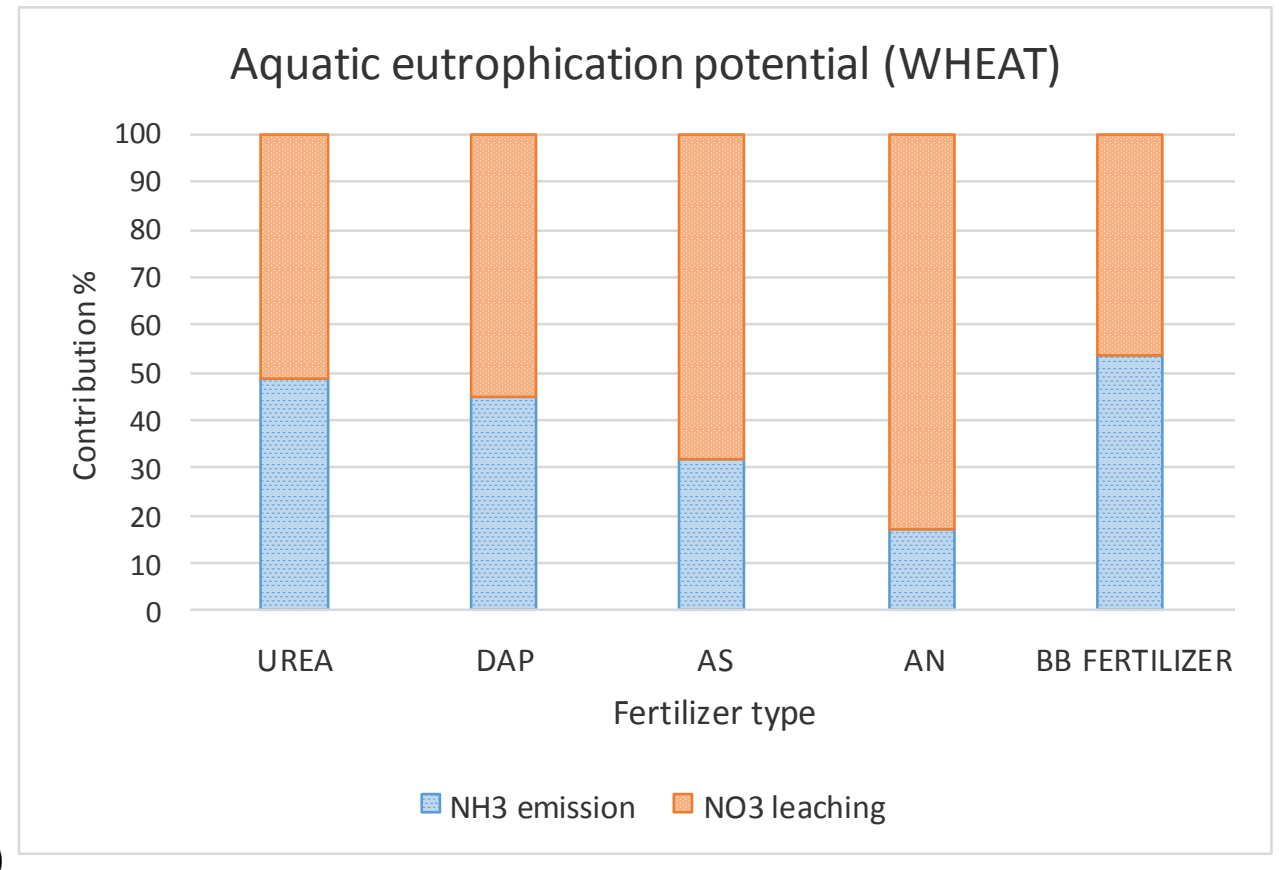

477

a)

Aquatic eutrophication potential (CORN)

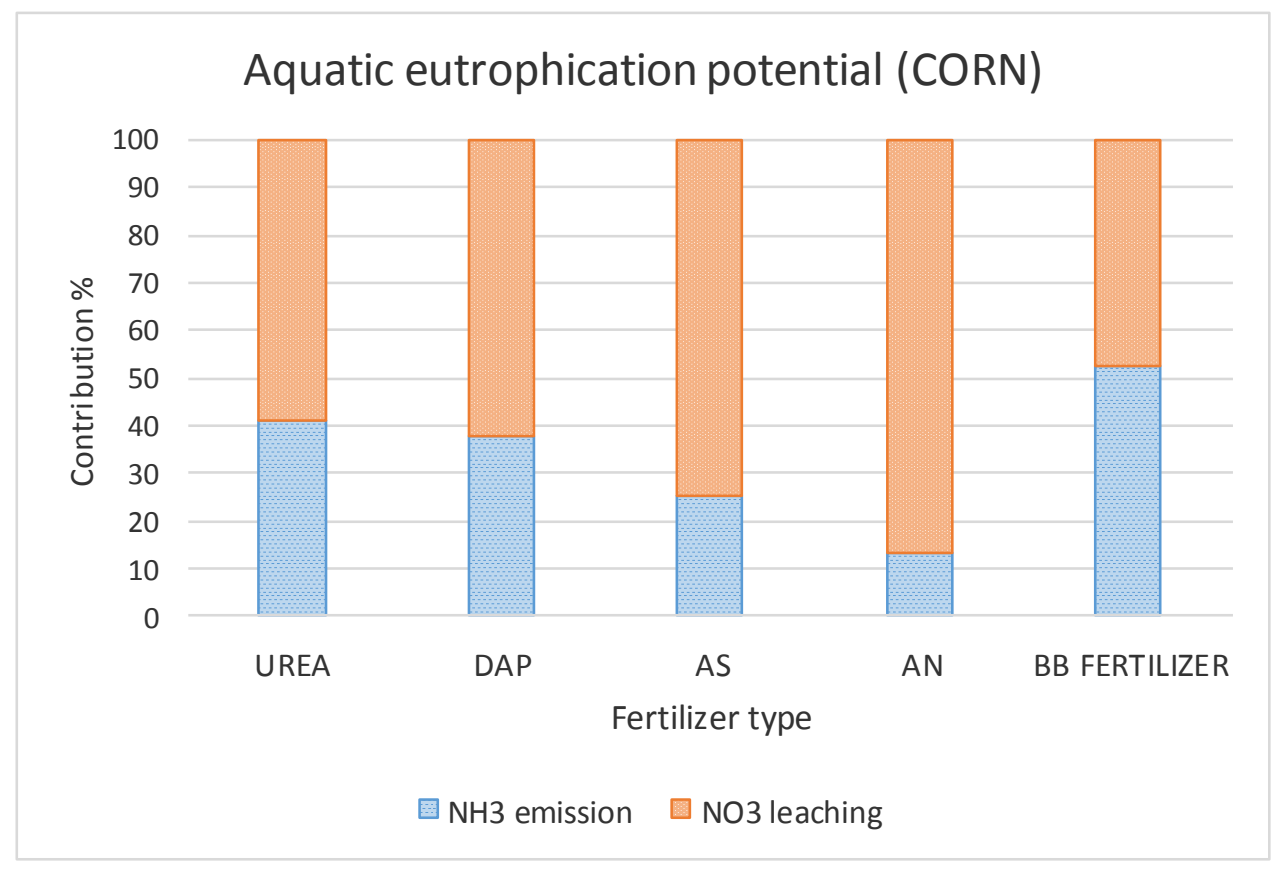

圆 NH3 emission $\square$ NO3 leaching

b)

Figure 5. Contribution of $\mathrm{NH}_{3}$ volatilization and $\mathrm{NO}_{3}$ leaching processes into the AEP impact category for each fertilizer applied to a) wheat and b) corn crops. 
a)

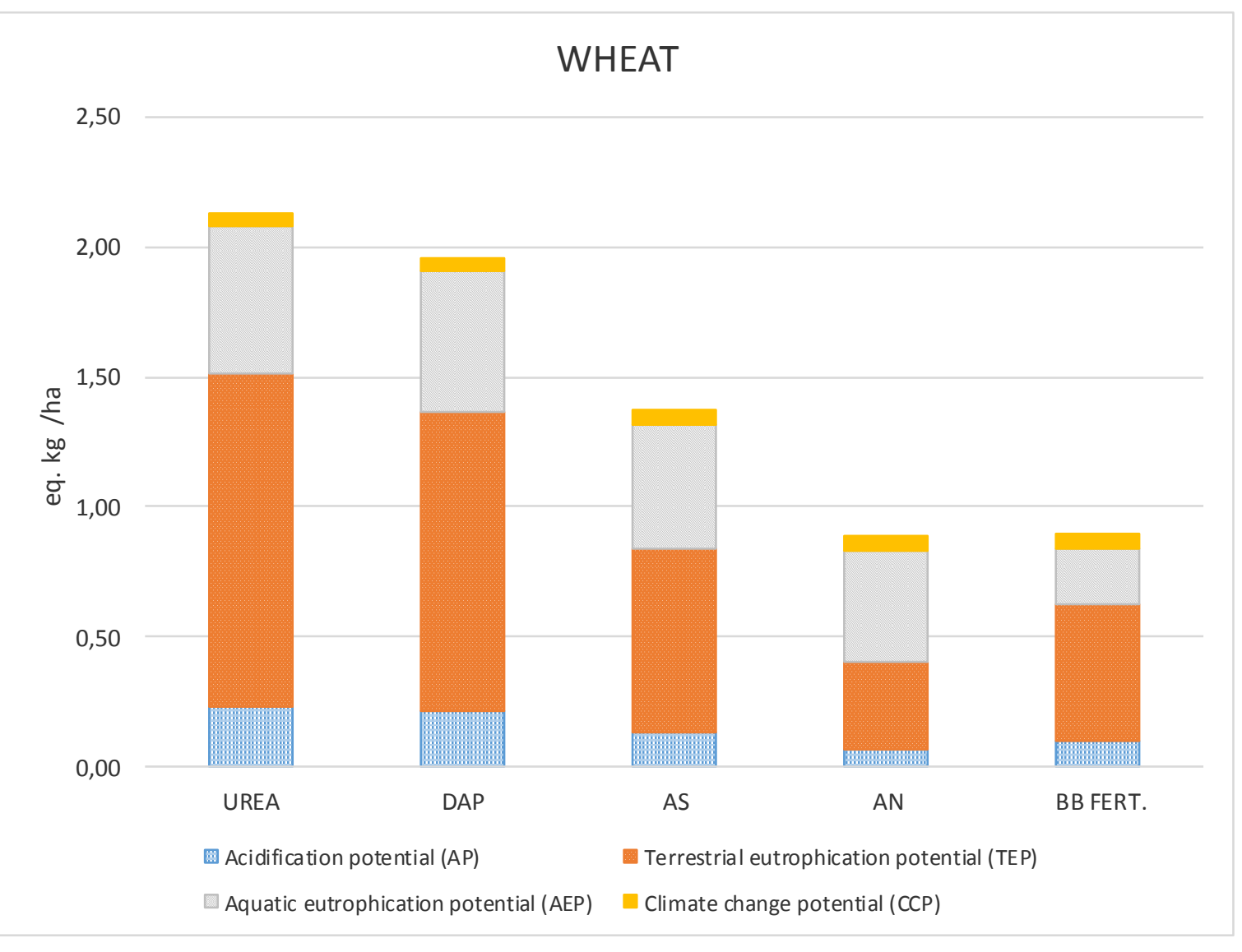


b)

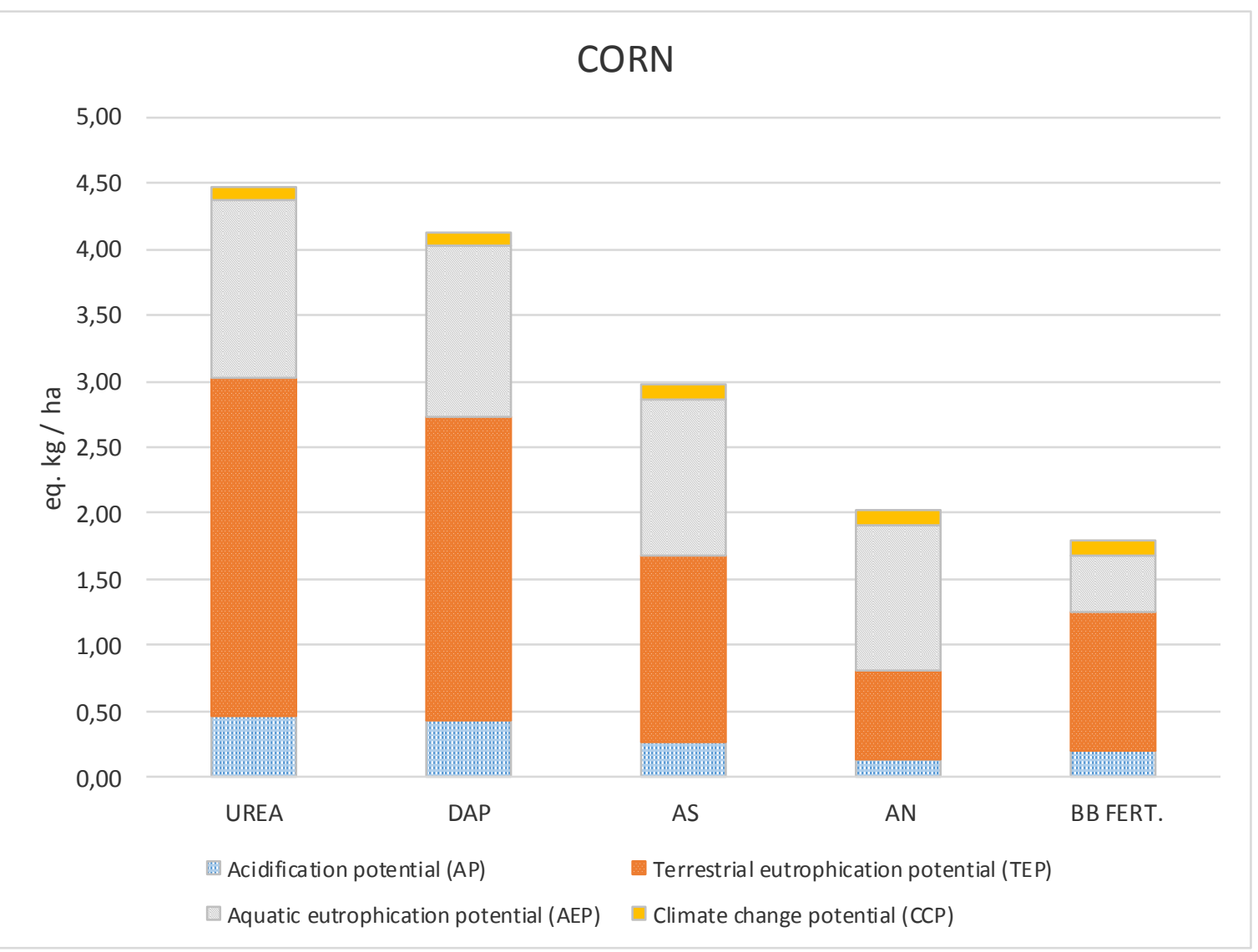

Figure 6. Impacts aggregation for each fertilizer in a) wheat crop, b) corn crop.

487 Figure 6 shows the aggregated values of all environmental risks derived from the application of 488 each fertilizer, indicating the distribution of pollution potentials. The highest value corresponds to 489 Urea (for both crops) and the lowest to the biochar-based fertilizer. The reduction of global 490 environmental damage achieved with biochar-based fertilizer is between $58 \%$ (vs urea on wheat 491 crop) and $11 \%$ (vs AN on corn crop) compared to traditional fertilizers.

492 Distribution of risks in the case of urea, DAP, AS and biochar-based fertilizer shows the prevalence 493 of terrestrial and aquatic eutrophication potential (both representing more than $80 \%$ of the total 494 risks in all cases), while for AN the most important risk is the aquatic eutrophication potential (55\% 495 for wheat and $58 \%$ for corn). 
496 Figures $7 a$ and $b$ show the contribution analysis of impacts in the application case of the analyzed

497 fertilizer products. Terrestrial eutrophication potential presents the largest contribution for all

498 fertilizers except for DAP for which the most important influence is aquatic eutrophication.

499 a)

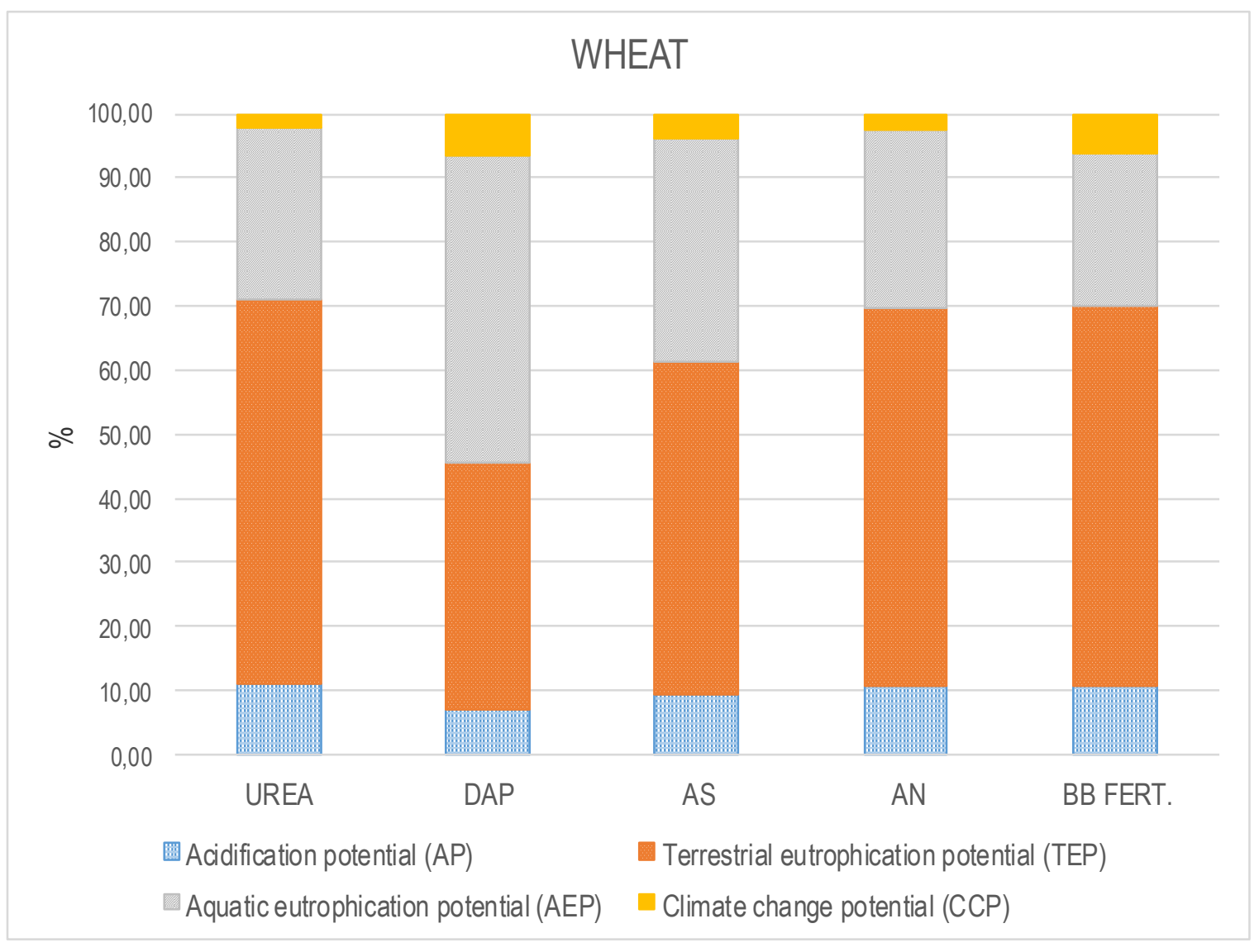




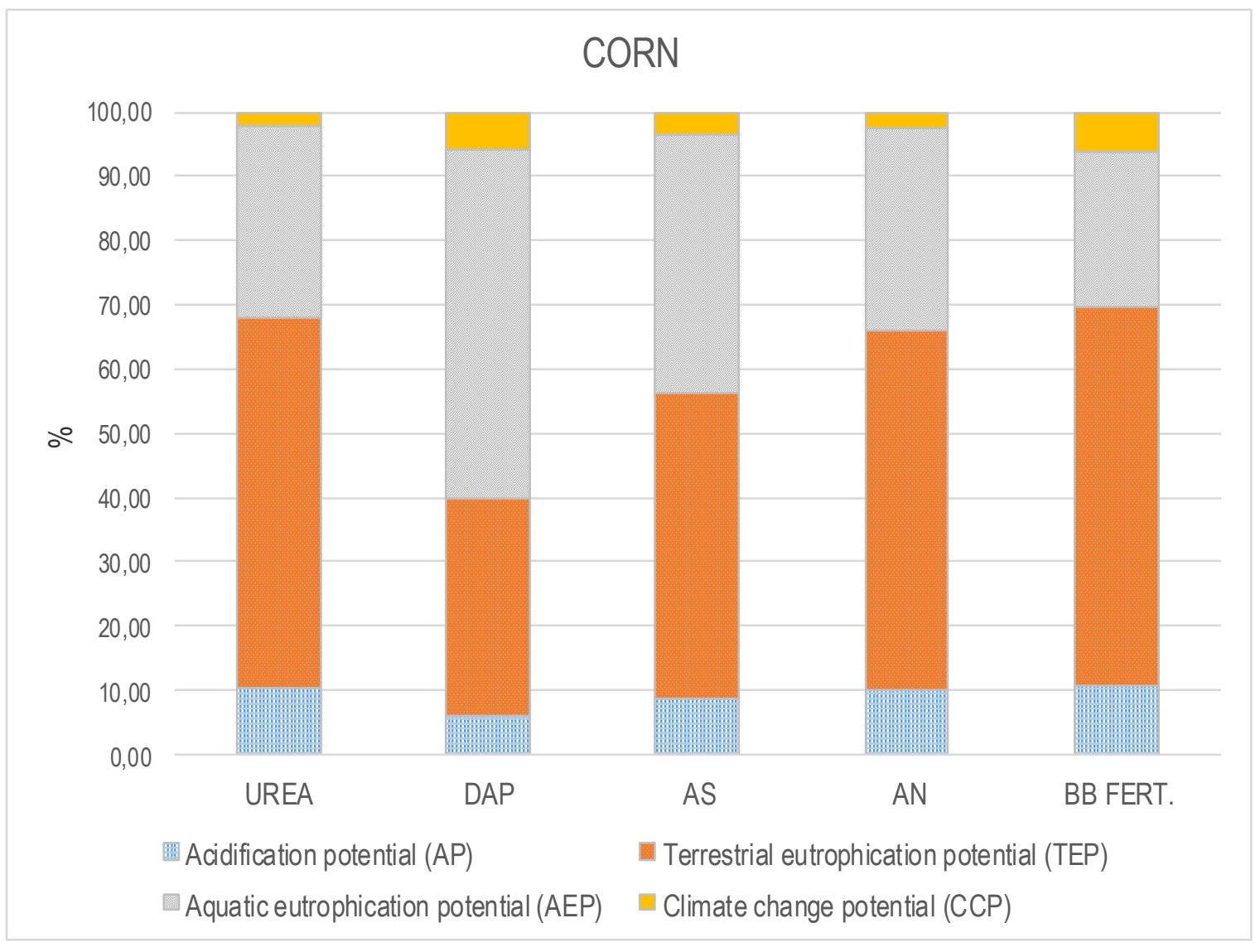

503 Figure 7. Contribution analysis of different impacts according to each fertilizer type for a) wheat and b) corn 504 crops. 
505

506

507

508

509

510

511 similar risk for the wheat crop while the biochar-based fertilizer shows a better environmental

512 behavior for the corn crop when a greater amount of fertilizer is used.

513

514 The analysis of $\mathrm{Nr}$ saving shows a substantial reduction in the amount of nitrogen released to the 515 environment for both crops when the biochar-based fertilizer is used. This is due to the difference

516 in the nitrogen percentage of each molecule $\left(\mathrm{NH}_{3}, \mathrm{NO}_{3}{ }^{-}\right.$or $\left.\mathrm{N}_{2} \mathrm{O}\right)$. This result penalizes traditional

517 fertilizers compared to new one which achieves a reduction of up to 63\% in the $\mathrm{Nr}$ content (when 518

Figure 8. Aggregated environmental indicator values (EcoX) per hectare from selected fertilizers applied to wheat and corn crops.

EcoX indicator (Figure 8) shows global results that allow categorizing fertilizers according to their global risk. In this sense, urea represents the highest environmental risk fertilizer for the two studied crops. However, according to this indicator AN and biochar-based fertilizer involve a

\subsection{Reactive nitrogen saving} compared to Urea for a corn crop).

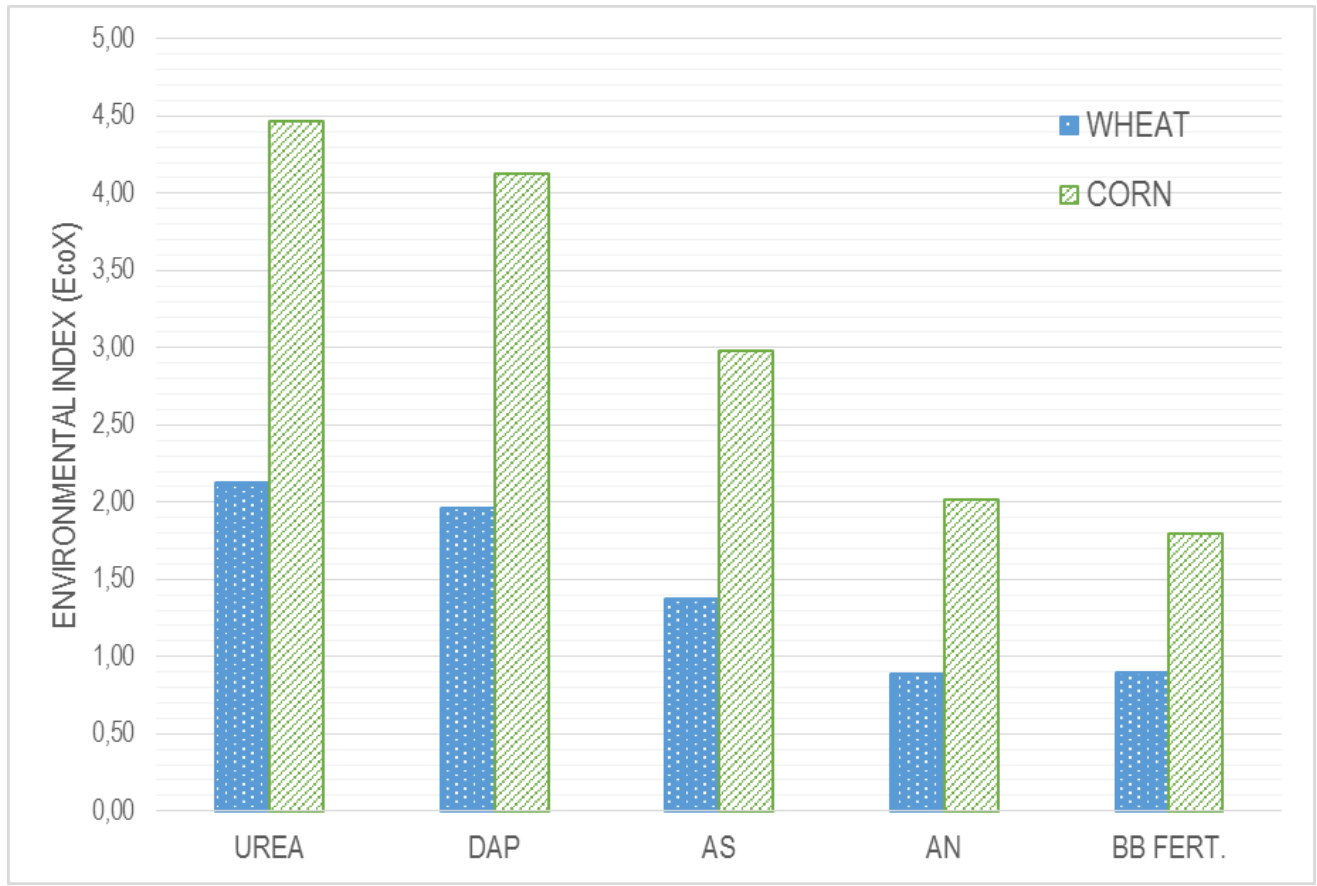




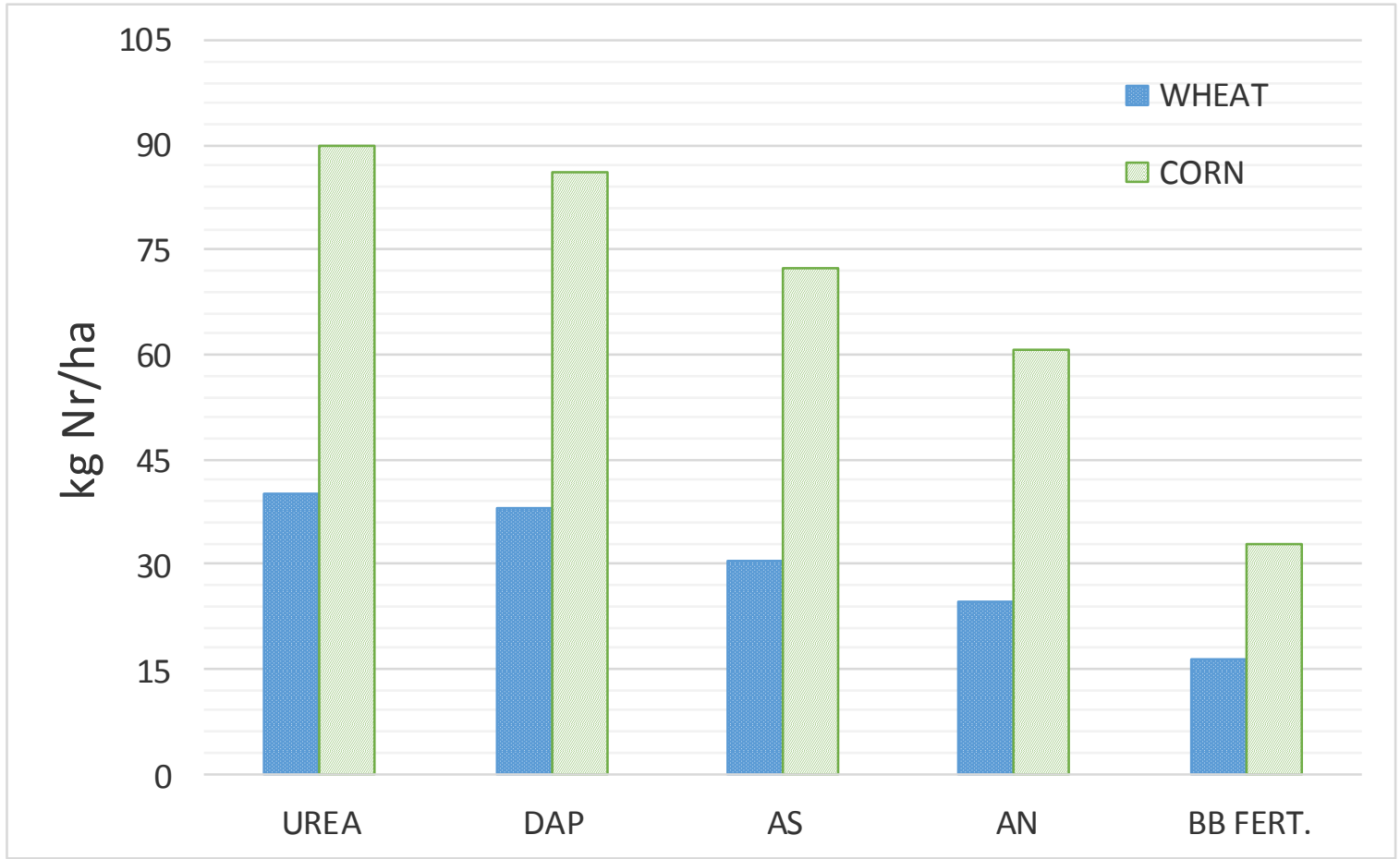

Figure 9. Reactive nitrogen released according to fertilizer type and crop (kg Nr / ha).

521 Figure 9 shows the total amount of reactive nitrogen released as a result of the application of each

522 fertilizer. For the present case study and considering both crops, the biochar-based fertilizer is the 523 product with the least nitrogen losses, $16,27 \mathrm{~kg} \mathrm{Nr} / \mathrm{ha}$ for wheat and 32,95 kg Nr/ha for corn. The

524 highest degree of $N_{r}$ savings is achieved with respect to urea, reaching almost $60 \%$ for wheat and $52563 \%$ for corn. The results for Nr savings are shown in Table 13, which clearly show that the new 526 fertilizer consistently achieves greater savings than the traditional ones for both crops.

\begin{tabular}{ccc}
\hline & \% Nr saving (wheat crop) & \% Nr saving (corn crop) \\
\hline Urea & 59,52 & 63,42 \\
AN & 33,46 & 45,84 \\
AS & 46,83 & 54,40 \\
DAP & 57,19 & 61,70
\end{tabular}


529 4. Conclusions

530 A new methodology for the environmental analysis of nitrogen fertilizers was developed and

531 implemented in this work basing on the calculation of reactive nitrogen saving, and it was used to 532 compare the potential risks associated to the application of different nitrogen fertilizers. The 533 proposed methodology was based on the life cycle analysis approach and the nitrogen footprint 534 tool, both developed in the agricultural field. By means of potential impact indicators, different 535 traditional mineral fertilizers and a biochar-based fertilizer were classified according to their 536 environmental risk. The study was developed considering local conditions and using predictive 537 models of volatilization and leaching based on bibliographic and experimental data.

538 From the obtained results, it can be concluded that:

539 - The proposed methodology is adequate for the assessment of the environmental risks involved in 540 the application of nitrogen fertilizers in agricultural practices. Its use allows to characterize 541 different types of fertilizer products according to their specific environmental risks.

542 - The methodology enables determining to which extent the substitution of traditional fertilizers 543 for the biochar-based fertilizer has a better performance in environmental terms.

544 - The application of this methodology to study the fertilization of two extensive cereal crops under 545 autochthonous conditions successfully assessed the environmental performance of four different 546 traditional fertilizers (urea, ammonium nitrate, ammonium sulphate and di-ammonium 547 phosphate) and a new biochar-based product. In order to do this, internally developed predictive 548 models were used to estimate nitrogen emissions derived from the use of the traditional 549 fertilizers, whereas experimental data was used to determine the value of emission factors for the 550 case of a biochar-based fertilizer. 
551 - Whereas aquatic eutrophication is the main risk associated to ammonium nitrate, for the other

552 three traditional fertilizers terrestrial eutrophication potential was identified as the most relevant

553 environmental damage. .

554 - The analysis of reactive nitrogen savings provides a new tool for assessing the environmental

555 benefit of a fertilizer. In this case, reactive nitrogen released by the application of the same

556 amount of nitrogen was analyzed in the form of different chemical products was studied for all the

557 considered fertilizers, which proved the biochar-based product to have the best environmental

558 performance among them (63,42\% saving of mineral nitrogen against urea).

559 As a result, it may me concluded that the use of biochar as fertilizer additive is a promising low-

560 cost alternative for the reduction of nitrogen contamination through nitrate leaching in

561 agricultural practice.

562 Acknowledgements

563 The work presented in this paper has been funded by the Spanish Ministry of Economy and

564 Competitiveness in RETOS-COLABORACIÓN program (Project RTC-2015-3411-5) co-financed by the 565 European Union with ERDF.

566

567 5. References

568 [1.] Skowronska, M. and Filipek, T. (2013) Life Cycle Assessment of Fertilizers: A Review. 569 International Agrophysics, 28, 101-110.

570 [2.] N. M Crawford, A. D.M Glass, (1998) Molecular and physiological aspects of nitrate uptake in 571 plants, Trends in Plant Science, (3), 10: 389-395. 
572 [3.] Galloway, J.N., Aber, J.D., Erisman, J.W., Seitzinger, S.P., Howarth, R.W., Cowling, E.B. and 573 Cosby, B.J. The nitrogen cascade (2003): BioScience, 53, (4), pp. 341-356.

574 [4.] J. W. Erisman, J. N. Galloway, N. B. Dise, M. A. Sutton, A. Bleeker, B. Grizzetti, A. M. Leach, 575 W. de Vries. Nitrógeno: un recurso vital en demasía. WWF Science Brief. (2005).

576 [5.] Spokas K.A., Novak J.M., Venterea R.T. (2012) Biochar's role as an alternative N-fertilizer: 577

[6.] K. Y. Chan, L. Van Zwieten, I. Meszaros, A. Downie \& S. Joseph, (2008) Agronomic values of

[7.] S. Gul, J.K. Whalen. (2016) Biochemical cycling of nitrogen and phosphorus in biocharamended soils. Soil Biology and Biochemistry 103:1-15.

[8.] G. Haider, D. Steffens, G. Moser, C. Müller, C. I. Kammann. Biochar reduced nitrate leaching and improved soil moisture content without yield improvements in a four-year field study, Agriculture, Ecosystems \& Environment, 237, (2017), 80-94.

[9.] A. M. Bass, M. I. Bird, G. Kay, B. Muirhead, Soil properties, greenhouse gas emissions and crop yield under compost, biochar and co-composted biochar in two tropical agronomic systems, Science of The Total Environment, 550, (2016), 459-470.

[10.] L. Yu, M. Yu, X. Lu, C. Tang, X. Liu, P. C. Brookes, J. Xu, Combined application of biochar and Environment, 640-641, (2018), 1221-1230.

[11.] J. Sadaf, G. A. Shah, K. Shahzad, N. Ali, M. Shahid, S. Ali, R. A. Hussain, Z. I. Ahmed, B. Traore, accomplish by co-application of biochars and chemical fertilizers, Science of The Total Environment, 607-608, (2017), 715-724. 
[12.] M. Plaza, Carbón activado evaluación de nuevos precursores y del proceso de activación con dióxido de carbono, Ph.D Thesis University of Alicante, 2015.

[13.] Marris, E. (2006). Putting the carbon back: black is the new green. Nature, 442, 624-626.

[14.] Steinbeiss, S., Gleixner, G. \& Antonietti, M. (2009). Effect of biochar amendment on soil carbon balance and soil microbial activity. Soil Biology and Biochemistry, 41, 1301-1310.

[15.] Van Zwieten, L., Kimber, S., Morris, S., Chan, K., Downie, A., Rust, J., Joshep, S. \& Cowie, A. (2010). Effects of biochar from slow pyrolysis of papermill waste on agronomic performance and soil fertility. Plant and soil, 327, 235-246.

[16.] Lehmann, J. \& Josegh, S. 2009. Biochar for environmental management: science and technology, Earthscan.

[17.] Singh, B. P., Hatton, B. J., Singh, B., Cowie, A. L. \& Kathuria, A. 2010. Influence of biochars on nitrous oxide emission and nitrogen leaching from two contrasting soils. Journal of Environmental Quality, 39, 1224- 1235.

[18.] Major, J., Steiner, C., Downie, A. \& Lehmann, J. 2009. Biochar effects on nutrient leaching. Biochar for environmental management: science and technology. Earthscan, London, 271-282.

[19.] Knowles, O., Robinson, B., Contangelo, A. \& Clucas, L. 2011. Biochar for the mitigation of nitrate leaching from soil amended with biosolids. Science of the total Environment, 409, 3206-3210.

[20.] Fallahpour M., Aminghafouri A., Ghalegolab Behbahani A. and Bannayan M. The environmental impact assessment of wheat and barley production by using life cycle assessment (LCA) methodology. (2012) Environ Dev. Sustain, 14, 979-992.

[21.] Brentrup F and Palliere C. GHG emissions and energy efficiency in European nitrogen fertilizer production and use. Proc. International Feriliser Society, (2008), York, UK. 
620

621

622

623

624

625

626

627

628

629

630

631

632

633

634

635

636

637

638

639

640

641

[22.] K. Hasler, S. Bröring, S.W.F. Omta, H.-W. Olfs, (2015). Life cycle assessment (LCA) of different fertilizer product types, European Journal of Agronomy, (69), 41-51.

[23.] J. Martínez-Blanco, P. Muñoz, A. Antón, J. Rieradevall, (2011). Assessment of tomato Mediterranean production in open-field and standard multi-tunnel greenhouse, with compost or mineral fertilizers, from an agricultural and environmental standpoint, Journal of Cleaner Production, (19), 9-10: 985-997.

[24.] M. Romero-Gámez, E.M. Suárez-Rey, A. Antón, N. Castilla, T. Soriano, (2012). Environmental impact of screenhouse and open-field cultivation using a life cycle analysis: the case study of green bean production, Journal of Cleaner Production, (28), 63-69.

[25.] M.T. Moreira, I. Noya, G. Feijoo, (2017). The prospective use of biochar as adsorption matrix - A review from a lifecycle perspective, Bioresource Technology, (246), 135-141.

[26.] J. Hammond, S. Shackley, S. Sohi, P. Brownsort, ( 2011). Prospective life cycle carbon abatement for pyrolysis biochar systems in the UK, Energy Policy, (39): 5, 2646-2655.

[27.] J. F. Peters, D. Iribarren, J. Dufour, (2015). Biomass Pyrolysis for Biochar or Energy Applications: A Life Cycle Assessment. Environmental Science \& Technology, 49 (8), 51955202.

[28.] K. G. Roberts, B. A. Gloy, S. Joseph, N. R. Scott, J. Lehmann, (2010). Life Cycle Assessment of Biochar Systems: Estimating the Energetic, Economic, and Climate Change Potential. Environmental Science \& Technology, 44 (2), 827-833.

[29.] V. Uusitalo, M. Leino, (2019). Neutralizing global warming impacts of crop production using biochar from side flows and buffer zones: A case study of oat production in the boreal climate zone, Journal of Cleaner Production, (227), 48-57. 
642 [30.] Qian L., Chen L., Joseph S., Pan G.X., Li L., Zheng J., Zhang X., Zheng J., Yu X., and J. Wang. 643 (2014). Biochar compound fertilizer as an option to reach high productivity but low carbon 644 intensity in rice agriculture of China. Carbon Management. 5(2), 145-154.

645 [31.] S. Mandal, R. Thangarajan, N. S. Bolan, B. Sarkar, N. Khana, Y. S. Okd \& Ravi Naidu, Biochar646 induced concomitant decrease in ammonia volatilization and increase in nitrogen use 647 648 efficiency by wheat, Chemosphere 142 (2016) 120-127.

[32.] S. G. Sommer, C. Jensen, Ammonia volatilization from urea and ammoniacal fertilizers surface applied to winter wheat and grassland, Fertilizer Research 37 (1994) 85-92.

[33.] F. Viero, C.Bayer, S. M. V. Fontoura, R. P Moraes, Ammonia volatilization from nitrogen fertilizers in no-till wheat and maize in Southern Brazil. Brazilian Journal of Soil Science, 38 (2014) 1515-1525.

[34.] X. Peng, B. Maharjan, C. Yu, A. Su, V. Jin, \& R. B. Ferguson, A laboratory evaluation of 654 ammonia volatilization and nitrate leaching following nitrogen fertilizer application on a

[36.] B. C. A. Jones, R. T Koenig, J. W Ellsworth, B. D Brown \& G. D. Jackson, Management of urea coarse-textured soil. Agronomy Journal, 107 (2015)871-879.

[35.] F. Bayrakli, Ammonia volatilization losses from different fertilizers and effect of several urease inhibitors, $\mathrm{CaCl} 2$ and phosphogypsum on losses from urea. 4 (1990) 147-150.

661 [37.] G. X. Cai, D.L Chen, H. Ding, A. Pacholski, X.H Fan \& Z.L. Zhu, Nitrogen losses from fertilizers applied to maize, wheat and rice in the North China Plain, Nutrient Cycling in Agroecosystems, 63 (2002)187-195.

[38.] B. Raun \& H. Zhang. Nitrogen fertilizer sources, their potential losses and management tips. Oklahoma Cooperative Extension Service (2006). 
666

667

668

669

670

671

672

673

674

675

676

677

678

679

680

681

682

683

684

685

686

687

688

689

[39.] P. L. Barnes, L. D Maddux, Nitrate leaching. Kansas Fertilizer Report of Progess, (1982) 4852.

[40.] I.Sestak, M. Mesic, Z. Zgorelec, I. Kisic \& F.Basic, Winter wheat agronomic traits and nitrate leaching under variable nitrogen fertilization. Plant, Soil and Environment, 60 (2014) 394400.

[41.] Z Liu, T. He, T. Cao, T. Yang, J. Meng \& W. Chen, Effects of biochar application on nitrogen leaching, ammonia volatilization and nitrogen use efficiency in two distinct soils. Journal of Soil Science and Plant Nutrition, 17 (2017).

[42.] H. Fontanetto, O. Keller, C. Negro \& Leandro Belotti, Perdidas por volatilización de amoniaco de diferentes fuentes nitrogenadas en trigo bajo siembra directa, Miscelánea 105, (2006) 63-68.

[43.] Liying Sum, L. Li, Z. Chen, J. Wang \& Z. Xiong, Combined effects of nitrogen deposition and biochar application on emissions of $\mathrm{N} 2 \mathrm{O} \mathrm{CO} 2$ and NH3 from agricultural and forest soils, Soil Science and Plant Nutrition, 60 (2014) 254-265.

[44.] S. Gezgin \& F. Bayrakll, Ammonia volatilization from ammnium sulphate, ammonium nitrate and urea surface applied to winter wheat on a calcareous soil, Journal of Plant Nutrition, 18 (1995) 2483-2494

[45.] S. Shenbagavalli \& S. Mahimairaja, Characterization and effect of biochar on nitrogen and carbon dynamics in soil, Internal Journal of Advance Biological Research, 2 (2012) 249-255.

[46.] J.W. Lightner, D.B. Mengel, \& C.L.Rhykerd, Ammonia volatilization from fertilizers surface applied to orchardgrass sod, Soil Science Society of American Journal, 54 (1990) 1478-1482.

[47.] Y. Feng, H. Sun, L. Xue, Y. Liu, Q. Gao, K. Lu \& L. Yang, Biochar applied at an appropriate rate can avoid increasing $\mathrm{NH} 3$ volatilization dramatically in rice paddy soil, Chemosphere, 168 (2017) $1277-1284$. 
690

691

692

693

694

695

696

697

698

699

700

701

702

703

704

705

706

707

708

709

710

711

712

713

[48.] C.C. du Preez \& R. du T. Burger, Effect of application methods on ammonia volatilization from soils in a controlled environment, Plant and Soil 4(2) 1987 57-60.

[49.] C.C. du Preez \& R. du T. Burger; Laboratory measurements of ammonia volatilization from five nitrogen-containing after surface application at different rates on a neutral to alkaline soil, Plant and Soil 4(1) (1987) 17-20.

[50.] J. M. S Tumpe \& P.L.G. Vlen, L. lindsa, Ammonia volatilization from urea and urea phosphates in calcareous soils, Soil Science Society of America Journal, 48(4) (1984) 921927.

[51.] M. Prasad, Gaseous loss of ammonia from sulfur-coated urea, ammonium sulfate, and urea applied to calcareous soil (pH 7.3), Soil Science Society of America Journal, 40(1) (1975) 130134.

[52.] L. B. Fenn \& D. E. Kissel, The influence of cation exchange capacity and depth of incorporation on ammonia volatilization from ammonium compounds applied to calcareous soils, Soil Science Society of America Journa 40 (1976) 394-398.

[53.] T.J. Van der Weerden, Ammonia emission factors for $N$ fertilizers applied to two contrasting grasslands soils. Environmental Pollution, 95(2) (1997) 205-211.

[54.] X. Cheng, Effect of biochar on NH3 volatilization and N2O emission in brown Soil., Advanced Materials Research, 1092-1093 (2015) 1229-1233

[55.] A.D.P. Botha \& D.C. Pretorius, Ammonia volatilization and denitrification losses from commercial fertilizers applied to soil samples. South African Journal of Plant and Soil 5 (1988) 89-91.

[56.] C.C. Du Preez \& R. Du t. Burger, Ammonia losses from ammonium-containing and forming fertilizers after surface application at different rates on alkaline soils, Fertilizer Research 15 (1988)71-78. 
714 [57.] J. K. R. Gasser, Some factors affecting losses of ammonia from urea and ammonium 715 Sulphate applied to soils, Journal of Soil Science, 15(2) (1964) 258-272.

716 [58.] G. N. Ferraris, L. A. Couretot, M. Toribio, Pérdidas de nitrógeno por volatilización y su 717 implicancia en el rendimiento del cultivo de maíz en pergamino (Bs AS). Efectos de fuente, 718 dosis y uso de inhibidores, www.fertilizando.com (consultado 15/6/2018).

719 [59.] J. Purakayastha \& J.C. Katyal, Evaluation of compacted urea fertilizers prepared with acid 720

[60.] E. Perming. Nitrogen Footprint Vs. Life Cycle Impact Assessment methods - A comparison of the methods in a case study. Master Degree Thesis in Atmospheric Sciences and Biogeochemical Cycles, Lund University (2012).

[61.] M. Ahmad, A. U. Rajapaksha, J. E. Lim, M. Zhang, N. Bolan, D. Mohan, M. Vithanage, S. S. Lee, Y. S. Ok, (2014). Biochar as a sorbent for contaminant management in soil and water: A review, Chemosphere (99), 19-33.

[62.] Agricultural Productions: Cereals, Ministry of Agriculture, Fishing, Food and Environment. Government of Spain, 2017, http://www.mapama.gob.es/en/ visited 23/1/2018.

[63.] A. Marcilla, S. García-García, M. Asensio, J.A. Conesa, Influence of thermal treatment regime on the density and reactivity of activated carbons from almond shells, Carbon 38 (2000) $429-440$.

[64.] C. Okutucu, G. Duman, S. Ucar, I. Yasa, J. Yanik, Production of fungicidal oil and activated carbon from pistachio shell, J. Anal. Appl. Pyrol. 91 (2011) 140-146.

[65.] A.N.A. El-Hendawy, S.E. Samra, B.S. Girgis, Adsorption characteristics of activated carbons obtained from corncobs, Colloid. Surface. Physicochem. Eng. Aspect. 180 (2001) 209-221. 
737

738

739

740

741

742

743

744

[66.] Pallarés, J., González-Cencerrado, A., Arauzo, I. (2018) Production and characterization of activated carbon from barley straw by physical activation with carbon dioxide and steam. Biomass and bioenergy 115:64-73.

[67.] P. García-Serrano Jiménez, J. J. Lucena Marotta, S. Ruano Criado, M. Nogales García. Guía práctica de la fertilización racional de los cultivos en España. Ministerio de medio ambiente y medio rural y marino. Secretaría General Técnica, Centro de Publicaciones, (2010).

[68.] D. Gómez Orea, M. Gomez Villarino. Consultoría e ingeniería ambiental: planes, programas, proyectos, estudios, instrumentos de control ambiental, dirección y ejecución ambiental de obra, gestión ambiental de actividades, Mundi-Prensa, 2007.

[69.] Análisis de ciclo de vida y huella de carbono. IHOBE S.A. Publicación Gobierno Vasco.

[70.] Brentrup, F., Küsters, J., Lammel (2000). Methods to estimate on-field nitrogen emissions from crop production as an input to LCA studies in the agricultural sector. Int. J. LCA 5: 349.

[71.] Bouwman, A.F. Compilation of a global inventory of emissions of nitrous oxide. Ph.D. thesis, University of Wageningen, (1995), Netherlands.

[72.] J. M. Sánchez Pérez, I. Antiguedad, I. Arrate, C. García-Linares, I. Morell, The influence of nitrate leaching through unsaturated soil on groundwater pollution in an agricultural area of the Basque country: a case study, Science of The Total Environment, Volume 317, Issues 13, 2003, 173-187.

[73.] F Brentrup, J Küsters, J Lammel, P Barraclough, H Kuhlmann, Environmental impact assessment of agricultural production systems using the life cycle assessment (LCA) methodology II. The application to $\mathrm{N}$ fertilizer use in winter wheat production systems. Eur J Agron 20 (2004) 265-279.

[74.] N. P. Cheremisinoff, Chapter 31 - Pollution Management and Responsible Care, Editor(s): T. M. Letcher, D. A. Vallero, Waste, Academic Press, (2011), 487-502. 
761 [75.] International Organization for Standardizarion (ISO), Environmental management-life cycle 762 assessment-life cycle impact assessment. International standard ISO 14042:2000. ISO,

763

764

765

766

767

768

769

770

771

772

773

774

775

776

777

778

779

780

781

782

783

784 Geneva.

[76.] F. Brentrup, J. Küsters, H. Kuhlmann, J. Lammel, (2004) Environmental impact assessment of agricultural production systems using the life cycle assessment methodology: I. Theoretical concept of a LCA method tailored to crop production, European Journal of Agronomy (20) 3: 247-264.

[77.] Finnveden, G., Potting, J. (1999). Eutrophication as an impact category. State of the art and research needs. Int. J. LCA 4, 311-314.

[78.] Huijbregts, M.A.J. Uncertainty and variability in environmental life-cycle assessment. PhD thesis, University of Amsterdam, Amsterdam , (2001).

[79.] Huijbregts, M.A.J., Seppälä, J. Towards region-specific, European fate factors for airborne nitrogen compounds causing aquatic eutrophication. Int. J. LCA, (2000) 5, 65-67.

[80.] Potting, J. (Ed.), Beusen, A.H.W., Øllgaard, H., Hansen, O.C., de Haan, B., Hauschild, M., (2000). The Danish LCA methodology project. Technical report chapter on aquatic eutrophication, method development and consensus project. Department of Manufacturing Engineering and Management, Technical University of Denmark, Lyngby.

[81.] IPCC, 2007: Climate Change 2007: Synthesis Report. Contribution of Working Groups I, II and III to the Fourth Assessment Report of the Intergovernmental Panel on Climate Change [Core Writing Team, Pachauri, R.K and Reisinger, A. (eds.)]. IPCC, Geneva, Switzerland, 104 pp.

[82.] A. M. Leach, J. N. Galloway, A. Bleeker, J. W. Erisman, R. Kohn, J. Kitzes, (2012) A nitrogen footprint model to help consumers understand their role in nitrogen losses to the environment, Environmental Development (1), 1:40-66. 